\title{
Expedient Synthesis of Potent Cannabinoid Receptor Agonist (-)-CP55,940
}

\author{
Noriaki Itagaki, Tsutomu Sugahara, and Yoshiharu Iwabuchi ${ }^{\square}$ \\ Graduate School of Pharmaceutical Sciences, Tohoku University \\ Aobayama, Sendai 980-8578, Japan \\ Fax: +81-22-795-6845 \\ E-mail: iwabuchi@mail.pharm.tohoku.ac.jp
}

\section{Supporting Information}

Table of Contents

1. General

2. Experimental Procedures

(1) Preparation of chiral building block [(+)-5]

S-2

(2) Preparation of the amino acid catalyst

S-4

(3) Preparation of the aromatic component of CP 55,940

S-5

(4) Synthesis of CP 55,940 (3)

S-8

3. References

S-13

4. NMR spectra

S-14 


\section{General.}

IBX ${ }^{1}$ was prepared according to the literature procedures. Other chemicals and solvents were purchased from commercial suppliers or purified by standard techniques. All reactions were stirred magnetically, under an argon atmosphere, unless otherwise noted, and monitored with analytical TLC (Merck Kieselgel 60 $\left.F_{254}\right)$. Column chromatography was carried out with silica gel 60 particle size 0.063-0.210 mm. Melting points were taken with Yazawa BY-2 and are uncorrected. NMR spectra were measured in JEOL JNM-AL400 (400 MHz) or JEOL ECA600 (600 MHz). Chemical shifts were reported in the b scale relative to tetramethylsilane (TMS) as $0.00 \mathrm{ppm}$ for ${ }^{1} \mathrm{H}\left(\mathrm{CDCl}_{3}\right)$ and residual $\mathrm{CHCl}_{3}(7.26$ ppm for ${ }^{1} \mathrm{H}$ and $77.00 \mathrm{ppm}$ for ${ }^{13} \mathrm{C}$ ), as internal reference. The infrared (IR) spectra were recorded on JASCO IR-700 or JASCO FT/IR-410. Mass spectra were measured on JEOL JMS-DX303 (for low resolution MS) and JMS-AX500 or JMS-700 (for high resolution MS) instruments. The specific rotations were measured on JASCO DIP-370. Elemental analyses utilized Yanaco CHN CORDER MT-6.

\section{Experimental procedures.}

(1) Preparation of chiral building block [(+)-5]

$(1 R, 5 S, 8 S)-8$-hydroxybicyclo[3.3.1]nonan-2-one $\quad[(+)-2]: A$ solution of ketoaldehyde 1 (100mg, $0.648 \mathrm{mmol}$ ) in $\mathrm{MeCN}$ (2.6 ml) was added dropwisely to a stirred solution of $(2 R, 4 R)-4$-TBDPSoxy-D-proline $(60 \mathrm{mg}, 0.16 \mathrm{mmol})$ in $\operatorname{MeCN}(2.6 \mathrm{ml})$ at room temperature. The reaction mixture was stirred for $23 \mathrm{~h}$ at room temperature. Then, the mixture was concentrated under reduced pressure and the residue was purified by silica gel column chromatography [hexaneAcOEt $(4: 1 \mathrm{v} / \mathrm{v})$ ] to afford hydroxyketone $(+)-2(68 \mathrm{mg}, 68 \%)$ as colorless needles. An aliquot sample was recrystallized from diisopropyl ether-hexane.

$\mathrm{mp} 131-133^{\circ} \mathrm{C} ;[]_{D}{ }^{31}=+2.00^{\circ}\left(c 0.8, \mathrm{CHCl}_{3}\right)$. [lit. $\left.^{2}[]_{\mathrm{D}}{ }^{20}=+3.6^{\circ}\left(c 0.65, \mathrm{CHCl}_{3}\right)\right]$; IR $\left(\mathrm{CHCl}_{3}\right.$ solution): $3520,1700 \mathrm{~cm}^{-1} ;{ }^{1} \mathrm{H}-\mathrm{NMR}\left(400 \mathrm{MHz}, \mathrm{CDCl}_{3}\right)$ b: $3.78(\mathrm{~m}, 1 \mathrm{H})$, 2.79 (br. s, $1 \mathrm{H}), 2.66(\mathrm{~s}, 1 \mathrm{H}), 2.54(\mathrm{~m}, 1 \mathrm{H}), 2.37(\mathrm{~m}, 1 \mathrm{H}), 2.18-2.05(\mathrm{~m}, 3 \mathrm{H}), 1.97$ $(\mathrm{m}, 1 \mathrm{H}) 1.69(\mathrm{~m}, 4 \mathrm{H}), 1.38(\mathrm{~m}, 1 \mathrm{H}) ;{ }^{13} \mathrm{C}-\mathrm{NMR}\left(100 \mathrm{MHz}, \mathrm{CDCl}_{3}\right)$ b: 216.3, 71.6, 51.6, 39.0, 31.0, 30.7, 29.7, 26.7, 24.9; MS m/z : $154\left(\mathrm{M}^{+}\right), 70$ (100\%); HRMS Calcd. $\mathrm{C}_{9} \mathrm{H}_{14} \mathrm{O}_{2}:$ 154.0993. Found: 154.0983; Anal. Calcd. for $\mathrm{C}_{9} \mathrm{H}_{14} \mathrm{O}_{2}:$ C, 70.10 ; 
H, 9.15. Found: C, 70.05; H, 9.13.

(1R,5S,8S)-8-methoxymethoxybicyclo[3.3.1]nonan-2-one [(-)-4]: $\mathrm{MOMCl}$ $(0.22 \mathrm{ml}, 2.90 \mathrm{mmol})$ and diisopropylethylamine $(0.62 \mathrm{ml}, 3.56 \mathrm{mmol})$ was added to a stirred solution of alcohol (+)-2 (250 mg, $1.62 \mathrm{mmol},>99 \%$ ee) at room temperature and the mixture was stirred for $18 \mathrm{~h}$ at the same temperature. Then, the reaction mixture was diluted with $\mathrm{Et}_{2} \mathrm{O}$ and washed with $\mathrm{H}_{2} \mathrm{O}$. The aqueous layer was extracted with $\mathrm{Et}_{2} \mathrm{O}$ and the combined organic extract was washed with brine, dried over $\mathrm{MgSO}_{4}$, and concentrated under reduced pressure. The residue was purified by silica gel column chromatography [hexane-AcOEt (17:3 $\mathrm{v} / \mathrm{v})$ ] to afford ether (-)-4 (323 mg, $100 \%)$ as a colorless oil.

[]$_{D}{ }^{29}=-0.60^{\circ}$ (c 1.06, $\mathrm{CHCl}_{3}$ ); IR (neat): $1702 \mathrm{~cm}^{-1} ;{ }^{1} \mathrm{H}-\mathrm{NMR}\left(400 \mathrm{MHz}, \mathrm{CDCl}_{3}\right.$ ) b: $4.76(\mathrm{dd}, 1 \mathrm{H}, J=7.1,1.5 \mathrm{~Hz}), 4.61(\mathrm{dd}, 1 \mathrm{H}, J=6.8,1.5 \mathrm{~Hz}), 3.85(\mathrm{~m}, 1 \mathrm{H}), 3.37$ (d, 3H, J=1.5 Hz), 2.88 (br.s, $1 \mathrm{H}), 2.56-2.41(\mathrm{~m}, 2 \mathrm{H}), 2.09-1.68(\mathrm{~m}, 9 \mathrm{H}) ;{ }^{13} \mathrm{C}-$ NMR (100 MHz, $\mathrm{CDCl}_{3}$ ) b: 211.6, 94.0, 74.9, 55.3, 50.4, 40.2, 32.4, 30.3, 29.7, 28.3, 25.9; MS m/z : $198\left(\mathrm{M}^{+}\right), 45$ (100\%); HRMS Calcd. $\mathrm{C}_{11} \mathrm{H}_{18} \mathrm{O}_{3}: 198.1255$. Found: 198.1239; Anal. Calcd. for $\mathrm{C}_{11} \mathrm{H}_{18} \mathrm{O}_{3}: \mathrm{C}, 66.64 ; \mathrm{H}, 9.15$. Found: C, 66.59; $\mathrm{H}, 8.96$.

(1R,5R,8S)-8-methoxymethoxybicyclo[3.3.1]non-3-en-2-one [(+)-5]: IBX (3.33 $\mathrm{g}, 11.9 \mathrm{mmol})$ was added to a solution of ketone (-)-4 (590 mg, $2.98 \mathrm{mmol})$ in toluene-DMSO $(29.7 \mathrm{ml}, 2: 1 \mathrm{v} / \mathrm{v})$ at room temperature. The mixture was heated to $55-75^{\circ} \mathrm{C}$ and stirred for $11 \mathrm{~h}$. After cooling, the reaction mixture was diluted with $\mathrm{Et}_{2} \mathrm{O}$, filtered through a Celite pad, and the organic solution was washed with saturated aqueous $\mathrm{NaHCO}_{3}$ and $\mathrm{H}_{2} \mathrm{O}$. The aqueous layer was extracted with $\mathrm{Et}_{2} \mathrm{O}$ and the combined organic extract was washed with brine, dried over $\mathrm{MgSO}_{4}$, and concentrated under reduced pressure. The residue was purified by silica gel column chromatography [hexane-AcOEt $(4: 1 \mathrm{v} / \mathrm{v})$ ] to afford enone (+)-5 (470 $\mathrm{mg}, 80 \%)$ as a colorless oil.

[]$_{\mathrm{D}}{ }^{28}=+18.4^{\circ}\left(\mathrm{c} 0.95, \mathrm{CHCl}_{3}\right)$; IR (neat): $1671 \mathrm{~cm}^{-1} ;{ }^{1} \mathrm{H}-\mathrm{NMR}\left(400 \mathrm{MHz}, \mathrm{CDCl}_{3}\right.$ ) b: $6.90(\mathrm{dd}, 1 \mathrm{H}, J=9.0,6.8 \mathrm{~Hz}), 6.20(\mathrm{~d}, 1 \mathrm{H}, J=9.8 \mathrm{~Hz}), 4.82(\mathrm{~d}, 1 \mathrm{H}, J=6.8 \mathrm{~Hz})$, $4.64(\mathrm{~d}, 1 \mathrm{H}, J=6.8 \mathrm{~Hz}), 3.76(\mathrm{~m}, 1 \mathrm{H}), 3.40$ (s, 3H), 2.83 (br.s, 1H), 2.57 (br.s, $1 \mathrm{H}), 2.32(\mathrm{~d}, 1 \mathrm{H}, J=10.5 \mathrm{~Hz}), 1.91(\mathrm{~m}, 1 \mathrm{H}), 1.80-1.62(\mathrm{~m}, 4 \mathrm{H}) ;{ }^{13} \mathrm{C}-\mathrm{NMR}(100$ 
$\mathrm{MHz}, \mathrm{CDCl}_{3}$ ) b: 199.3, 151.2, 132.3, 94.1, 73.7, 55.5, 47.1, 33.3, 29.9, 25.7, 25.0; MS m/z : $196\left(\mathrm{M}^{+}\right), 45$ (100\%); HRMS Calcd. $\mathrm{C}_{11} \mathrm{H}_{16} \mathrm{O}_{3}:$ 196.1099. Found: 196.1075; Anal. Calcd. for $\mathrm{C}_{11} \mathrm{H}_{16} \mathrm{O}_{3}$ : C, 67.32; H, 8.22. Found: C, 67.03; H, 7.96. The enantiomeric purity of $(+)-5$ was determined to be $>99 \%$ ee by chiral HPLC analysis using DAICEL CHIRALCEL OD. The conditions used for the analysis of 5 and the retention time were as follows; Solvent: $i$-PrOH-hexane (3:97). Flow rate: $0.5 \mathrm{ml} / \mathrm{min}$. Retention time: (1S,5S,8R)-5; $20.0 \mathrm{~min},(1 R, 5 R, 8 S)-5 ; 22.1 \mathrm{~min}$

(2) Preparation of the amino acid catalyst

The catalyst 14 was synthesized as shown in the following scheme.

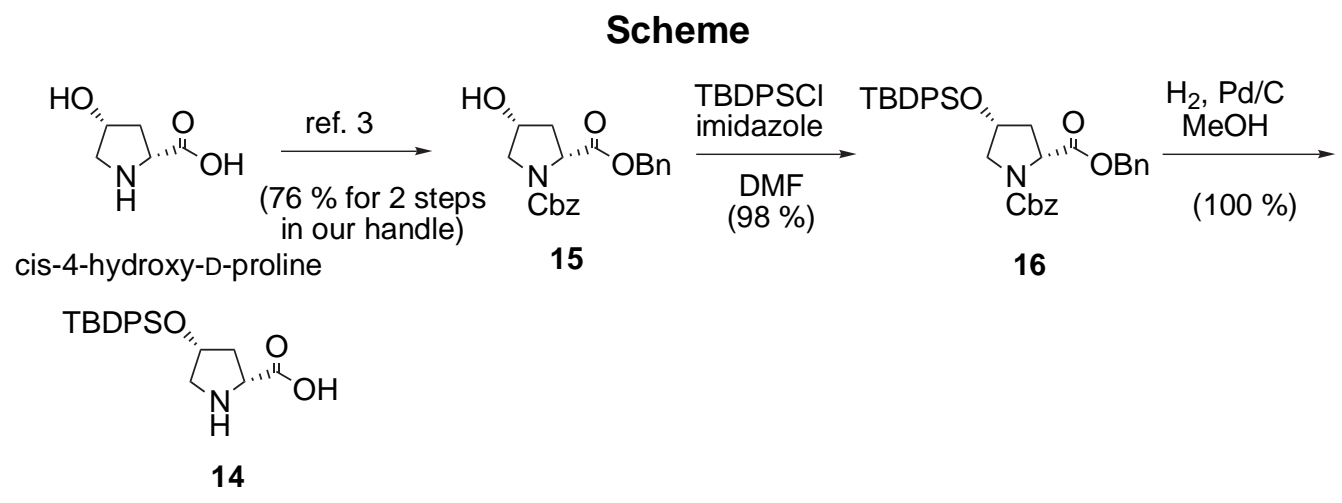
dibenzyl ester [(+)-16]: TBDPSCl (1.54 ml, $5.92 \mathrm{mmol})$ and imidazole (804 mg, $11.8 \mathrm{mmol}$ ) were added to a solution of alcohol $15(1.75 \mathrm{~g}, 34.8 \mathrm{mmol})$ in DMF $(5.0 \mathrm{ml})$ at room temperature. The reaction mixture was stirred for $24 \mathrm{~h}$ at the same temperature. Then, the reaction mixture was diluted with $\mathrm{Et}_{2} \mathrm{O}$ and the organic solution was washed with $\mathrm{H}_{2} \mathrm{O}$. The aqueous layer was extracted with $\mathrm{Et}_{2} \mathrm{O}$ and the combined organic solution was washed with brine, dried over $\mathrm{MgSO}_{4}$, and concentrated under reduced pressure. The residue was purified by silica gel column chromatography [hexane-AcOEt $(97: 3 \mathrm{v} / \mathrm{v})$ ] to afford silyl ether (+)-16 (2.852 $\mathrm{g}, 98 \%)$ as a colorless oil.

[]$_{\mathrm{D}}{ }^{28}=+26.5^{\circ}\left(\mathrm{c} 0.84, \mathrm{CHCl}_{3}\right)$; IR (neat): $1798,1747 \mathrm{~cm}^{-1} ;{ }^{1} \mathrm{H}-\mathrm{NMR}(400 \mathrm{MHz}$, $\left.\mathrm{CDCl}_{3}\right)$ b: $7.62-7.23(\mathrm{~m}, 2 \mathrm{H}), 5.19-4.97\left(\mathrm{~m}\right.$, total $\left.4 \mathrm{H}_{\text {rotamer }}\right), 4.50\left(\mathrm{dd}, 0.5 \mathrm{H}_{\text {rotamer }}, J\right.$ $=8.8,3.4 \mathrm{~Hz}), 4.40\left(\mathrm{dd}, 0.5 \mathrm{H}_{\text {rotamer }}, J=8.8,3.9 \mathrm{~Hz}\right), 4.32(\mathrm{~m}, 1 \mathrm{H}), 3.57(\mathrm{~d}, 1 \mathrm{H}, J=$ 
4.4 Hz), $3.49(\mathrm{~m}, 1 \mathrm{H}), 2.28-2.12(\mathrm{~m}, 2 \mathrm{H}), 1.03$ and 1.02 (each s, total $9 \mathrm{H}_{\text {rotamer }}$ ); ${ }^{13} \mathrm{C}-\mathrm{NMR}\left(100 \mathrm{MHz}, \mathrm{CDCl}_{3}\right.$ ) (rotamer) b: 171.5, 171.2, 154.7, 154.2, 136.5, 136.3, 135.6, 135.5, 135.4, 133.2, 133.1, 133.0, 129.8, 129.7, 128.39, 128.37, 128.3, $128.2,128.1,128.0,127.9,127.80,127.76,127.72,127.7,127.68,127.64$, 127.6, 71.6, 70.7, 67.03, 66.95, 66.9, 66.8, 58.02, 57.77, 54.9, 54.4, 39.3, 38.4, 26.7, 19.0; MS m/z : $536\left(\mathrm{M}^{+}-\mathrm{C}_{4} \mathrm{H}_{9}\right), 91$ (100\%). HRMS Calcd. $\mathrm{C}_{32} \mathrm{H}_{30} \mathrm{NO}_{5} \mathrm{Si}$ $\left(\mathrm{M}^{+}-\mathrm{C}_{4} \mathrm{H}_{9}\right): 536.1891$. Found : 536.1899; Anal. Calcd. for $\mathrm{C}_{36} \mathrm{H}_{39} \mathrm{NO}_{5} \mathrm{Si}: \mathrm{C}, 72.82$; $\mathrm{H}, 6.62 ; \mathrm{N}, 2.36$. Found: C, 72.75; $\mathrm{H}, 6.51 ; \mathrm{N}, 2.40$.

(2R,4R)-4-(tert-butyldiphenylsilyloxy)-D-proline [(+)-14]: $10 \%(\mathrm{w} / \mathrm{w}) \mathrm{Pd} / \mathrm{C}$ (255 mg) was added to a solution of ester-carbamate (+)-16 (2.550 g, 4.29 $\mathrm{mmol})$ in $\mathrm{MeOH}(23.3 \mathrm{ml})$ and the mixture was stirred under atmospheric pressure of $\mathrm{H}_{2}$ for $48 \mathrm{~h}$ at room temperature. Then, the reaction mixture was filtered through a Celite pad, and concentrated under reduced pressure to afford amino acid (+)-14 (1.583 g, $100 \%)$ as a colorless solid.

$\mathrm{mp} 137-138.5^{\circ} \mathrm{C}$; []$_{\mathrm{D}}{ }^{27}=+3.85^{\circ}\left(\mathrm{c} 0.7, \mathrm{CH}_{3} \mathrm{OH}\right.$ ); IR (nujol): $3404,1714 \mathrm{~cm}^{-1}$. ${ }^{1} \mathrm{H}-\mathrm{NMR}\left(400 \mathrm{MHz}, \mathrm{CD}_{3} \mathrm{OD}\right)$ b: 7.67-7.63 (m, 4H), 7.48-7.39 (m, 6H), 4.50 (br.s, $1 \mathrm{H}), 4.24(\mathrm{~m}, 1 \mathrm{H}), 3,34(\mathrm{~d}, 1 \mathrm{H}, J=12.2 \mathrm{~Hz}), 3.18(\mathrm{q}, 1 \mathrm{H}, J=12.2,3.7 \mathrm{~Hz}), 2.39$ $(\mathrm{m}, 1 \mathrm{H}), 2.29(\mathrm{~m}, 1 \mathrm{H}), 1.05(\mathrm{~s}, 9 \mathrm{H}) ;{ }^{13} \mathrm{C}-\mathrm{NMR}\left(100 \mathrm{MHz}, \mathrm{CD}_{3} \mathrm{OD}\right)$ b: 172.7, 136.93, 136.87, 134.1, 133.9, 131.29, 131.27, 129.1, 129.0, 72.9, 60.4, 54.9, 39.4, 27.2, 19.8; MS m/z : $312\left(\mathrm{M}^{+}-\mathrm{C}_{4} \mathrm{H}_{9}\right), 234$ (100\%). HRMS Calcd. $\mathrm{C}_{17} \mathrm{H}_{18} \mathrm{NO}_{3} \mathrm{Si}\left(\mathrm{M}^{+}-\mathrm{C}_{4} \mathrm{H}_{9}\right): 312.1055$. Found : 312.1022 .

(3) Preparation of the aromatic component of CP 55,940

Trifluoromethanesulfonic acid 4-(1,1-dimethylheptyl)-2,6-dimethoxyphenyl ester: 2,4,6-Collidine $(17.3 \mathrm{ml}, 130 \mathrm{mmol})$ and trifluoromethanesulfonic anhydride $(6.48 \mathrm{ml}, 38.5 \mathrm{mmol})$ were added to a stirred solution of 4-(1,1dimethylhepthyl)-2,6-dimethoxyphenol $(9.00 \mathrm{~g}, 32.1 \mathrm{mmol})$ in $\mathrm{CH}_{2} \mathrm{Cl}_{2}(160 \mathrm{ml})$ at $0{ }^{\circ} \mathrm{C}$ and stirring was continued for $24 \mathrm{~h}$ at the same temperature. Then, the mixture was diluted with $\mathrm{Et}_{2} \mathrm{O}$ and washed with $\mathrm{H}_{2} \mathrm{O}$. The aqueous layer was extracted with $\mathrm{Et}_{2} \mathrm{O}$ and the combined organic extract was washed with brine, dried over $\mathrm{MgSO}_{4}$, and concentrated under reduced pressure. The residue was purified by silica gel column chromatography [hexane-AcOEt $(19: 1 \mathrm{v} / \mathrm{v})$ ] to afford 
triflate $(10.55 \mathrm{~g}, 80 \%)$ as colorless needles.

mp 34-35 ${ }^{\circ} \mathrm{C}$; IR (neat): 1603, 1415, $1203 \mathrm{~cm}^{-1} ;{ }^{1} \mathrm{H}-\mathrm{NMR}\left(400 \mathrm{MHz}, \mathrm{CDCl}_{3}\right.$ ) b: $6.55(\mathrm{~s}, 2 \mathrm{H}), 3.87(\mathrm{~s}, 6 \mathrm{H}), 1.56(\mathrm{~m}, 2 \mathrm{H}), 1.28(\mathrm{~s}, 6 \mathrm{H}), 1.28-1.18(\mathrm{~m}, 6 \mathrm{H}), 1.06(\mathrm{~m}$, $2 \mathrm{H}), 0.85$ (t, 3H, J = 6.8 Hz); ${ }^{13} \mathrm{C}-\mathrm{NMR}\left(100 \mathrm{MHz}, \mathrm{CDCl}_{3}\right)$ b: 151.6, 151.1, 125.7, 118.6 (q, $J=318 \mathrm{~Hz}$ ), 102.7, 56.1, 44.5, 38.5, 31.7, 30.0, 29.0, 24.6, 22.7, 14.1; MS m/z: $412\left(\mathrm{M}^{+}\right), 279$ (100\%); HRMS Calcd. $\mathrm{C}_{18} \mathrm{H}_{27} \mathrm{~F}_{3} \mathrm{O}_{5} \mathrm{~S}: 412.1530$. Found: 412.1528; Anal. Calcd. for $\mathrm{C}_{18} \mathrm{H}_{27} \mathrm{~F}_{3} \mathrm{O}_{5} \mathrm{~S}$ : C, 52.41; $\mathrm{H}, 6.60$. Found: C, 52.34; $\mathrm{H}$, 6.51.

1-(1,1-Dimethylheptyl)-3,5-dimethoxybenzene (8): $\mathrm{Et}_{3} \mathrm{~N}^{4}(8.7 \mathrm{ml}, 62.4 \mathrm{mmol})$ and $10 \%(\mathrm{w} / \mathrm{w}) \quad \mathrm{Pd} / \mathrm{C} \quad(10.0 \mathrm{~g})$ were added to a solution of trifluoromethanesulfonic acid 4-(1,1-dimethylheptyl)-2,6-dimethoxyphenyl ester $(10.30 \mathrm{~g}, 24.97 \mathrm{mmol})$ in $\mathrm{MeOH}(190 \mathrm{ml})$ at room temperature and the mixture was stirred under atmospheric pressure of $\mathrm{H}_{2}$ for 8 days at the same temperature. Then, the reaction mixture was filtered through a Celite pad eluting with $\mathrm{MeOH}$, and concentrated under reduced pressure. The residue was purified by silica gel column chromatography [hexane-AcOEt $(19: 1 \mathrm{v} / \mathrm{v})$ ] to afford $t$ alkyldimethoxybenzene 8 (5.385 g, $82 \%)$ as a colorless oil.

IR (neat): $1602 \mathrm{~cm}^{-1}$; ${ }^{1} \mathrm{H}-\mathrm{NMR}\left(400 \mathrm{MHz}, \mathrm{CDCl}_{3}\right.$ ) b: 6.40 (d, $\left.2 \mathrm{H}, J=2.2 \mathrm{~Hz}\right), 6.22$ (t, $1 \mathrm{H}, J=2.2 \mathrm{~Hz}), 3.71(\mathrm{~s}, 6 \mathrm{H}), 1.48(\mathrm{~m}, 2 \mathrm{H}), 1.18(\mathrm{~s}, 6 \mathrm{H}), 1.20-1.07(\mathrm{~m}, 6 \mathrm{H})$, $0.98(\mathrm{~m}, 2 \mathrm{H}), 0.77$ (t, 3H, $J=7.1 \mathrm{~Hz}) ;{ }^{13} \mathrm{C}-\mathrm{NMR}\left(100 \mathrm{MHz}, \mathrm{CDCl}_{3}\right)$ b: 160.3, 152.4, 104.6, 96.5, 55.1, 44.5, 38.0, 31.8, 30.0, 28.9, 24.6, 22.7, 14.1; MS m/z: 264 $\left(\mathrm{M}^{+}\right), 180$ (100\%); HRMS Calcd. $\mathrm{C}_{17} \mathrm{H}_{28} \mathrm{O}_{2}: 264.2088$. Found: 264.2095.

3-(1,1-Dimethylheptyl)-5-methoxyphenol: 1-Propanethiol (19.8 ml, $219 \mathrm{mmol})$ was added to a suspension of $\mathrm{NaH}(60 \%)(3.60 \mathrm{~g}, 90.0 \mathrm{mmol})$ in DMF $(400 \mathrm{ml})$ at room temperature and the mixture was stirred for $30 \mathrm{~min}$ at the same temperature. Then, to the mixture was added a solution of $t$ alkyldimethoxybenzene 8 (4.971 $\mathrm{g}, 18.8 \mathrm{mmol})$ in DMF $(100 \mathrm{ml})$ and the reaction mixture was stirred for $20 \mathrm{~h}$ at $120{ }^{\circ} \mathrm{C}$. After cooling to room temperature, $10 \%$ aqueous $\mathrm{HCl}$ was added to this and the mixture was extracted with $\mathrm{Et}_{2} \mathrm{O}$ and washed with $\mathrm{H}_{2} \mathrm{O}$. The aqueous layer was extracted with $\mathrm{Et}_{2} \mathrm{O}$ and the combined organic extract was washed with brine, dried over $\mathrm{MgSO}_{4}$, and 
concentrated under reduced pressure. The residue was purified by silica gel column chromatography [hexane-AcOEt $(19: 1 \mathrm{v} / \mathrm{v})$ ] to afford phenol $(3.196 \mathrm{~g}$, $68 \%)$ as a colorless oil.

IR (neat): 3378, $1594 \mathrm{~cm}^{-1}$; ${ }^{1} \mathrm{H}-\mathrm{NMR}\left(400 \mathrm{MHz}, \mathrm{CDCl}_{3}\right.$ ) b: 6.47 (t, $\left.1 \mathrm{H}, J=1.8 \mathrm{~Hz}\right)$, 6.40 (t, $1 \mathrm{H}, J=1.8 \mathrm{~Hz}), 6.23$ (t, 1H, J=2.2 Hz), 4.89 (br.s, 1H), 3.77 (s, 3H), 1.53 $(\mathrm{m}, 2 \mathrm{H}), 1.23(\mathrm{~s}, 6 \mathrm{H}), 1.25-1.16(\mathrm{~m}, 6 \mathrm{H}), 1.04(\mathrm{~m}, 2 \mathrm{H}), 0.84(\mathrm{t}, 3 \mathrm{H}, J=7.0 \mathrm{~Hz})$; ${ }^{13} \mathrm{C}-\mathrm{NMR}\left(100 \mathrm{MHz}, \mathrm{CDCl}_{3}\right)$ b: 160.3, 156.2, 152.9, 105.7, 105.0, 97.9, 55.2, 44.5, 37.8, 31.8, 30.0, 28.9, 24.7, 22.7, 14.1; MS m/z : $264\left(\mathrm{M}^{+}\right), 166$ (100\%); HRMS Calcd. $\mathrm{C}_{16} \mathrm{H}_{26} \mathrm{O}_{2}: 250.1931$. Found: 250.1944 .

Trifluoromethanesulfonic acid 3-(1,1-dimethylheptyl)-5-methoxyphenyl ester: $2,4,6$-Collidine $(6.86 \mathrm{ml}, 51.6 \mathrm{mmol})$ and trifluoromethanesulfonic anhydride $(2.58 \mathrm{ml}, 15.3 \mathrm{mmol})$ were added to a stirred solution of 3-(1,1dimethylheptyl)-5-methoxyphenol $(3.196 \mathrm{~g}, 12.76 \mathrm{mmol})$ in $\mathrm{CH}_{2} \mathrm{Cl}_{2}(64 \mathrm{ml})$ at $0{ }^{\circ} \mathrm{C}$ and stirring was continued for $24 \mathrm{~h}$ at the same temperature. Then, the mixture was diluted with $\mathrm{Et}_{2} \mathrm{O}$ and washed with $\mathrm{H}_{2} \mathrm{O}$. The aqueous layer was extracted with $\mathrm{Et}_{2} \mathrm{O}$ and the combined organic extract was washed with brine, dried over $\mathrm{MgSO}_{4}$, and concentrated under reduced pressure. The residue was purified by silica gel column chromatography [hexane-AcOEt $(19: 1 \mathrm{v} / \mathrm{v})$ ] to afford triflate $(4.569 \mathrm{~g}, 87 \%)$ as colorless oil.

IR (neat): 1618, 1582, 1422, $1210 \mathrm{~cm}^{-1} ;{ }^{1} \mathrm{H}-\mathrm{NMR}\left(400 \mathrm{MHz}, \mathrm{CDCl}_{3}\right)$ b: 6.88 (s, 1H), $6.81(\mathrm{~s}, 1 \mathrm{H}), 6.62(\mathrm{~s}, 1 \mathrm{H}), 3.80(\mathrm{~s}, 3 \mathrm{H}), 1.57(\mathrm{~m}, 2 \mathrm{H}), 1.27(\mathrm{~s}, 6 \mathrm{H}), 1.28-1.17$ $(\mathrm{m}, 6 \mathrm{H}), 1.03(\mathrm{~m}, 2 \mathrm{H}), 0.84(\mathrm{t}, 3 \mathrm{H}, J=6.7 \mathrm{~Hz}) ;{ }^{13} \mathrm{C}-\mathrm{NMR}\left(100 \mathrm{MHz}, \mathrm{CDCl}_{3}\right)$ b: 160.3, 153.6, 150.1, 118.7 (q, $J=318 \mathrm{~Hz}$ ), 112.6, 111.2, 103.5, 55.5, 44.4, 38.2, 31.7, 29.9, 28.7, 24.6, 22.7, 14.0 ; MS m/z : $382\left(\mathrm{M}^{+}\right), 297$ (100\%); HRMS Calcd. $\mathrm{C}_{17} \mathrm{H}_{25} \mathrm{~F}_{3} \mathrm{O}_{4} \mathrm{~S}: 382.1424$. Found: 382.1427 .

1-(1,1-Dimethylheptyl)-3-methoxybenzene: $\mathrm{Et}_{3} \mathrm{~N}^{4}(2.91 \mathrm{ml}, 20.9 \mathrm{mmol})$ and $10 \%(\mathrm{w} / \mathrm{w}) \mathrm{Pd} / \mathrm{C}(3.2 \mathrm{~g})$ were added to a solution of trifluoromethanesulfonic acid 3-(1,1-dimethylheptyl)-5-methoxyphenyl ester $(3.196 \mathrm{~g}, 8.36 \mathrm{mmol})$ in $\mathrm{MeOH}(50 \mathrm{ml})$ at room temperature and the mixture was stirred under atmospheric pressure of $\mathrm{H}_{2}$ for 5 days at the same temperature. Then, the reaction mixture was filtered through a Celite pad, and concentrated under 
reduced pressure. The residue was purified by silica gel column chromatography [hexane-AcOEt (19:1 v/v)] to afford t-alkylmethoxybenzene (1.97 g, quant.) as a colorless oil.

IR (neat): $1579 \mathrm{~cm}^{-1} ;{ }^{1} \mathrm{H}-\mathrm{NMR}\left(400 \mathrm{MHz}, \mathrm{CDCl}_{3}\right)$ b: $7.21(\mathrm{~m}, 1 \mathrm{H}), 6.90(\mathrm{~m}, 2 \mathrm{H})$, $6.70(\mathrm{~m}, 1 \mathrm{H}), 3.78(\mathrm{~d}, 3 \mathrm{H}, J=3.2 \mathrm{~Hz}), 1.58(\mathrm{~m}, 2 \mathrm{H}), 1.28(\mathrm{~s}, 6 \mathrm{H}), 1.28-1.16(\mathrm{~m}$, $6 \mathrm{H}), 1.07$ (br.s, 2H), 0.84 (m, 3H); ${ }^{13} \mathrm{C}-\mathrm{NMR}\left(100 \mathrm{MHz}, \mathrm{CDCl}_{3}\right.$ ) b: 159.2, 151.5, $128.7,118.3,112.5,109.6,55.0,44.6,37.8,31.8,30.1$, 29.0, 24.7, 22.7, 14.1; MS m/z : $234\left(\mathrm{M}^{+}\right), 149(100 \%)$; HRMS Calcd. $\mathrm{C}_{16} \mathrm{H}_{26} \mathrm{O}: 234.1982$. Found: 234.1969.

1-Bromo-4-(1,1-dimethylheptyl)-2-methoxybenzene (9): $\mathrm{Br}_{2}$ (0.65 ml, 12.7 $\mathrm{mmol})$ in $\mathrm{AcOH}(10 \mathrm{ml})$ was added dropwisely to a stirred solution of 1-(1,1dimethylheptyl)-3-methoxybenzene $(1.489 \mathrm{~g}, 6.35 \mathrm{mmol})$ in $\mathrm{AcOH}(30 \mathrm{ml})$ at room temperature. The mixture was stirred for $4 \mathrm{~h}$ at the same temperature. Then, the reaction mixture was quenched with $10 \%$ aqueous $\mathrm{Na}_{2} \mathrm{~S}_{2} \mathrm{O}_{3}$ and extracted with $\mathrm{Et}_{2} \mathrm{O}$ and washed with $\mathrm{H}_{2} \mathrm{O}$. The aqueous layer was extracted with $\mathrm{Et}_{2} \mathrm{O}$ and the combined organic extract was washed with brine, dried over $\mathrm{MgSO}_{4}$, and concentrated under reduced pressure. The residue was chromatographed using [hexane-AcOEt $(99: 1 \mathrm{v} / \mathrm{v})$ ] to afford bromobenzene 9 (1.74 g, $87 \%$ and 1-bromo-2-(1,1-dimethylheptyl)-4-methoxybenzene (153 mg, $7.7 \%)$ and 1,5-dibromo-2-(1,1-dimethylheptyl)-4-methoxybenzene (123 mg, $4.9 \%)$ as inseparable mixture.

IR (neat): $1571 \mathrm{~cm}^{-1}$; ${ }^{1} \mathrm{H}-\mathrm{NMR}\left(400 \mathrm{MHz}, \mathrm{CDCl}_{3}\right.$ ) b: $7.41(\mathrm{~d}, 1 \mathrm{H}, J=8.3 \mathrm{~Hz}), 6.85$ (d, $1 \mathrm{H}, J=2.2 \mathrm{~Hz}), 6.79$ (dd, $1 \mathrm{H}, J=8.3,2.0 \mathrm{~Hz}), 3.88(\mathrm{~s}, 3 \mathrm{H}), 1.57(\mathrm{~m}, 2 \mathrm{H}), 1.27$ (s, 6H), 1.27-1.17 (m, 6H), $1.05(\mathrm{~m}, 2 \mathrm{H}), 0.84(\mathrm{t}, 3 \mathrm{H}, J=7.0 \mathrm{~Hz}) ;{ }^{13} \mathrm{C}-\mathrm{NMR}(100$ $\mathrm{MHz}, \mathrm{CDCl}_{3}$ ) b: 155.3, 150.8, 132.4, 119.5, 110.0, 108.3, 56.1, 44.5, 37.9, 31.8, 30.0, 29.0, 24.6, 22.7, 14.1; MS m/z : $314\left(\mathrm{M}^{+},{ }^{81} \mathrm{Br}\right), 312\left(\mathrm{M}^{+},{ }^{79} \mathrm{Br}\right), 227$ (100\%); HRMS Calcd. $\mathrm{C}_{16} \mathrm{H}_{25}{ }^{79} \mathrm{BrO}$ : 312.1088. Found: 312.1077; Calcd. $\mathrm{C}_{16} \mathrm{H}_{25}{ }^{81} \mathrm{BrO}$ : 314.1068. Found: 314.1056.

(4) Synthesis of CP 55,940 (3)

(1R,4R,5R,8S)-4-[4-(1,1-Dimethylheptyl)-2-methoxyphenyl]-8methoxymethoxybicyclo[3.3.1]nonan-2-one [(+)-10]: An apparatus 
containing a mixture of $\mathrm{Mg}(120 \mathrm{mg}, 4.94 \mathrm{mmol})$ and a small amount of $\mathrm{I}_{2}$ was flame-dried from bottom to top. After cooling, to the mixture was added a solution of bromobenzene 9 (1.38 g, $4.40 \mathrm{mmol})$ in THF $(2.5 \mathrm{ml})$ and the mixture was stirred for $80 \mathrm{~min}$ at refluxing temperature to generate the corresponding Grignard reagent. After cooling, hexamethylphosphoric triamide $(0.67 \mathrm{ml}, 3.46$ mmol) was added to this at $0{ }^{\circ} \mathrm{C}$ and the whole mixture was added to $\mathrm{CuBruMe}_{2} \mathrm{~S}$ (72 mg, $0.35 \mathrm{mmol}$ ) in another flask at $0{ }^{\circ} \mathrm{C}$. The mixture was stirred for $25 \mathrm{~min}$ at the same temperature. Then, to the stirred mixture was added dropwisely a solution of bicyclononenone $(+)-5(340 \mathrm{mg}, 1.73 \mathrm{mmol})$ in THF $(5.5 \mathrm{ml})$ at $-78{ }^{\circ} \mathrm{C}$ and stirring was continued for $2 \mathrm{~h}$ at the same temperature. After the reaction mixture was quenched with saturated aqueous $\mathrm{NH}_{4} \mathrm{Cl}$, the mixture was filtered through a Celite pad, extracted with $\mathrm{Et}_{2} \mathrm{O}$ and washed with $\mathrm{H}_{2} \mathrm{O}$. The aqueous layer was extracted with $\mathrm{Et}_{2} \mathrm{O}$ and the combined organic extract was washed with brine, dried over $\mathrm{MgSO}_{4}$, and concentrated under reduced pressure. The residue was purified by silica gel column chromatography [hexane-AcOEt (19:1 $\mathrm{v} / \mathrm{v})$ ] to afford silyl enol ether as a colorless oil. To a solution of silyl enol ether in THF $(5.0 \mathrm{ml})$ was added $1.0 \mathrm{M}$ TBAF in THF $(3.46 \mathrm{ml}, 3.46 \mathrm{mmol})$ at room temperature and the mixture was stirred for $30 \mathrm{~min}$ at the same temperature. Then, the solvent was removed under reduced pressure, $\mathrm{Et}_{2} \mathrm{O}$ was added to this residue, and the organic solution was washed with $\mathrm{H}_{2} \mathrm{O}$. The aqueous layer was extracted with $\mathrm{Et}_{2} \mathrm{O}$ and the combined organic solution was washed with brine, dried over $\mathrm{MgSO}_{4}$, and concentrated under reduced pressure. The residue was purified by silica gel column chromatography [hexane-AcOEt $(9: 1 \mathrm{v} / \mathrm{v})$ ] to afford ketone $(+)-10$ (638 $\mathrm{mg}, 85 \%)$ as a colorless oil.

[]$_{D}{ }^{33}=+16.7^{\circ}\left(c 0.8, \mathrm{CHCl}_{3}\right)$; IR (neat): $1701,1608,1570 \mathrm{~cm}^{-1} ;{ }^{1} \mathrm{H}-\mathrm{NMR}(600$ $\mathrm{MHz}, \mathrm{CDCl}_{3}$ ) b: $6.94(\mathrm{~d}, 1 \mathrm{H}, J=5.5 \mathrm{~Hz}), 6.84(\mathrm{~d}, 1 \mathrm{H}, J=6.4 \mathrm{~Hz}), 6.80(\mathrm{~s}, 1 \mathrm{H})$, $4.82(\mathrm{~d}, 1 \mathrm{H}, J=4.6 \mathrm{~Hz}), 4.66(\mathrm{~d}, 1 \mathrm{H}, J=4.6 \mathrm{~Hz}), 3.86(\mathrm{~m}, 1 \mathrm{H}), 3.81(\mathrm{~s}, 3 \mathrm{H}), 3.58$ $(\mathrm{m}, 1 \mathrm{H}), 3.40(\mathrm{~d}, 3 \mathrm{H}, J=0.9 \mathrm{~Hz}), 2.88(\mathrm{br} . \mathrm{s}, 1 \mathrm{H}), 2.75(\mathrm{~m}, 2 \mathrm{H}), 2.15-2.06(\mathrm{~m}, 3 \mathrm{H})$, 1.98 (br.s, $1 \mathrm{H}), 1.81(\mathrm{~m}, 2 \mathrm{H}), 1.57-1.50(\mathrm{~m}, 3 \mathrm{H}), 1.26(\mathrm{~s}, 6 \mathrm{H}), 1.26-1.17(\mathrm{~m}, 6 \mathrm{H})$, $1.06(\mathrm{~m}, 2 \mathrm{H}), 0.84$ (t, 3H, J = 4.4 Hz); ${ }^{3} \mathrm{C}-\mathrm{NMR}\left(150 \mathrm{MHz}, \mathrm{CDCl}_{3}\right)$ b: 213.0, 156.1, 149.6, 131.7, 127.3, 118.0, 108.4, 94.4, 76.9, 55.6, 55.2, 49.7, 45.3, 44.6, 39.0, $37.8,32.1,31.8,31.1,30.1,29.2,28.2,27.9,24.7,22.7,14.1 ; \mathrm{MS} m / z: 430\left(\mathrm{M}^{+}\right)$, 398 (100\%); HRMS Calcd. $\mathrm{C}_{27} \mathrm{H}_{42} \mathrm{O}_{4}$ : 430.3081. Found: 430.3099.; Anal. Calcd. 
for $\mathrm{C}_{27} \mathrm{H}_{42} \mathrm{O}_{4}: \mathrm{C}, 75.31 ; \mathrm{H}, 9.83$. Found: C, 75.27; $\mathrm{H}, 9.68$.

(7R,8R)-7-[4-(1,1-Dimethylheptyl)-2-methoxyphenyl]-8-(2-[1,3]dioxolan-2ylethyl)-1,4-dioxaspiro[4.5]decane [(-)-11]: Etyleneglycol $(0.195 \mathrm{ml}, 3.49$ $\mathrm{mmol})$ and $p$-toluenesulfonic acid $(13.2 \mathrm{mg}, 0.69 \mathrm{mmol})$ were added to a solution of bicycloketone $(+)-10(300 \mathrm{mg}, 0.697 \mathrm{mmol})$ in xylene $(34.8 \mathrm{ml})$ at room temperature and the mixture was stirred for $1 \mathrm{~h}$ at refluxing temperature. After cooling to room temperature, the mixture was quenched with saturated aqueous $\mathrm{NH}_{4} \mathrm{Cl}$, extracted with $\mathrm{Et}_{2} \mathrm{O}$ and washed with $\mathrm{H}_{2} \mathrm{O}$. The aqueous layer was extracted with $\mathrm{Et}_{2} \mathrm{O}$ and the combined organic extract was washed with brine, dried over $\mathrm{MgSO}_{4}$, and concentrated under reduced pressure. The residue was purified by silica gel column chromatography [hexane-AcOEt $(9: 1 \mathrm{v} / \mathrm{v})$ ] to afford diketal (-)-11 (291 mg, $88 \%$ ) as a colorless oil.

[]$_{D}{ }^{31}=-13.9^{\circ}$ (c 0.6, $\mathrm{CHCl}_{3}$ ); IR (neat): $1608,1570 \mathrm{~cm}^{-1} ;{ }^{1} \mathrm{H}-\mathrm{NMR}(600 \mathrm{MHz}$, $\mathrm{CDCl}_{3}$ ) b: 7.01 (br, $\left.1 \mathrm{H}\right), 6.83$ (br.s, $\left.1 \mathrm{H}\right), 6.76(\mathrm{~s}, 1 \mathrm{H}), 4.61(\mathrm{t}, 1 \mathrm{H}, J=3.0 \mathrm{~Hz})$, 3.95-3.71 (m, 8H), 3.77 (s, 3H), 3.15 (br.s, $1 \mathrm{H}), 1.90-1.17(\mathrm{~m}, 24 \mathrm{H}), 1.04(\mathrm{~m}, 3 \mathrm{H})$, 0.83 (t, 3H, $J=4.6 \mathrm{~Hz}) ;{ }^{13} \mathrm{C}-\mathrm{NMR}\left(150 \mathrm{MHz}, \mathrm{CDCl}_{3}\right)$ b: 157.1, 148.7, 129.7, 126.1, 118.3, 109.2, 108.8, 105.2, 64.8, 64.7, 64.4, 64.2, 55.5, 44.8, 42.4, 41.4, 37.7, $37.2,35.0,31.8,31.2,30.1,29.3,29.0,27.5,24.7,22.7,14.2 ; \mathrm{MS} m / z: 474\left(\mathrm{M}^{+}\right)$, 331 (100\%); HRMS Calcd. $\mathrm{C}_{29} \mathrm{H}_{46} \mathrm{O}_{5}: 474.3343$. Found: 474.3336.

\section{3-\{(7R,8R)-7-[4-(1,1-Dimethylheptyl)-2-methoxyphenyl]-1,4-}

dioxaspiro[4.5]dec-8-yl\}propan-1-ol [(-)-12]: 2,6-Lutidine $(0.26 \mathrm{ml}, 2.23$ $\mathrm{mmol})$ and TESOTf $(0.336 \mathrm{ml}, 1.49 \mathrm{mmol})$ were added to a stirred solution of diketal (-)-11 (160 mg, $0.371 \mathrm{mmol})$ in $\mathrm{CH}_{2} \mathrm{Cl}_{2}(3.7 \mathrm{ml})$ at $0{ }^{\circ} \mathrm{C}$ and stirring was continued for 30 min at the same temperature. After $\mathrm{H}_{2} \mathrm{O}$ was added, the mixture was further stirred for $30 \mathrm{~min}$ at $0{ }^{\circ} \mathrm{C}$. Then. The mixture was extracted with $\mathrm{Et}_{2} \mathrm{O}$ and washed with $\mathrm{H}_{2} \mathrm{O}$. The aqueous layer was extracted with $\mathrm{Et}_{2} \mathrm{O}$ and the combined organic extract was washed with brine, dried over $\mathrm{MgSO}_{4}$, and concentrated under reduced pressure. Next, $\mathrm{NaBH}_{4}(14 \mathrm{mg}, 0.37 \mathrm{mmol}$ ) was added to a solution of this crude product in $\mathrm{MeOH}(4.5 \mathrm{ml})$ at $0^{\circ} \mathrm{C}$ and the mixture was stirred for $10 \mathrm{~min}$ at the same temperature. After the solvent was removed under reduced pressure, AcOEt was added to this residue, and the 
organic solution was washed with $\mathrm{H}_{2} \mathrm{O}$. The aqueous layer was extracted with AcOEt and the combined organic solution was washed with brine, dried over $\mathrm{MgSO}_{4}$, and concentrated under reduced pressure. The residue was purified by silica gel column chromatography [hexane-AcOEt (4:1 v/v)] to afford alcohol (-)$12(110 \mathrm{mg}, 75 \%)$ as a colorless oil.

[]$_{D}{ }^{30}=-10.2^{\circ}\left(c \quad 0.38, \mathrm{CHCl}_{3}\right)$; IR (neat): 3416, 1607, $1569 \mathrm{~cm}^{-1} ;{ }^{1} \mathrm{H}-\mathrm{NMR}(600$ $\mathrm{MHz}, \mathrm{CDCl}_{3}$ ) b: 7.00 (br.s, $\left.1 \mathrm{H}\right), 6.84$ (br.s, $\left.1 \mathrm{H}\right), 6.77$ (s, 1H), 3.97-3.88 (m, 4H), $3.78(\mathrm{~s}, 3 \mathrm{H}), 3.42(\mathrm{~m}, 2 \mathrm{H}), 3.17$ (br.s, $1 \mathrm{H}), 1.92-1.17(\mathrm{~m}, 24 \mathrm{H}), 1.04(\mathrm{~m}, 2 \mathrm{H}), 0.95$ $(\mathrm{m}, 1 \mathrm{H}), 0.83(\mathrm{t}, 3 \mathrm{H}, J=4.8 \mathrm{~Hz}) ;{ }^{13} \mathrm{C}-\mathrm{NMR}\left(150 \mathrm{MHz}, \mathrm{CDCl}_{3}\right)$ b: 157.0, 148.8, 130.0, 126.0, 118.3, 109.2, 108.8, 64.3, 64.2, 63.1, 55.6, 44.7, 42.4, 41.2, 37.7, 37.2, 35.0, 31.8, 30.0, 29.8, 29.3, 29.0, 24.7, 22.7, 14.1; MS m/z: $432\left(\mathrm{M}^{+}\right), 331$ (100\%); HRMS Calcd. $\mathrm{C}_{27} \mathrm{H}_{44} \mathrm{O}_{4}: 432.3237$. Found: 432.3246 .

\section{(3R,4R)-3-[4-(1,1-Dimethylheptyl)-2-methoxyphenyl]-4-(3-hydroxypropyl)}

cyclohexanone: $10 \%$ Aqueous $\mathrm{HCl}(10 \mathrm{ml})$ was added to a solution of ketal $(-)-12(150 \mathrm{mg}, 0.347 \mathrm{mmol})$ in $\mathrm{THF}(3 \mathrm{ml})$ at $0{ }^{\circ} \mathrm{C}$ and the mixture was stirred for $32 \mathrm{~h}$ at the same temperature. After neutralization with $15 \%$ aqueous $\mathrm{NaOH}$, the mixture was extracted with AcOEt and washed with $\mathrm{H}_{2} \mathrm{O}$. The aqueous layer was extracted with AcOEt and the combined organic solution was washed with brine, dried over $\mathrm{MgSO}_{4}$, and concentrated under reduced pressure. The residue was purified by silica gel column chromatography [hexane-AcOEt (4:1-3:1 v/v)] to afford ketoalcohol (114 mg, $85 \%$ ) as a colorless oil.

[]$_{\mathrm{D}}{ }^{30}=-47.5^{\circ}$ (c 2.05, $\mathrm{CHCl}_{3}$ ); IR (neat): 3436, 1706, 1607, $1571 \mathrm{~cm}^{-1} ;{ }^{1} \mathrm{H}-\mathrm{NMR}$ $\left(600 \mathrm{MHz}, \mathrm{CDCl}_{3}\right)$ b: $7.03(\mathrm{~d}, 1 \mathrm{H}, J=5.5 \mathrm{~Hz}), 6.87(\mathrm{~d}, 1 \mathrm{H}, J=5.5 \mathrm{~Hz}), 6.80$ (s, $1 \mathrm{H}), 3.79(\mathrm{~s}, 3 \mathrm{H}), 3.46(\mathrm{~m}, 2 \mathrm{H}), 3.12(\mathrm{~m}, 1 \mathrm{H}), 2.63(\mathrm{t}, 1 \mathrm{H}, J=8.9 \mathrm{~Hz}), 2.43(\mathrm{~m}$, $3 \mathrm{H}), 2.21(\mathrm{~m}, 1 \mathrm{H}), 2.11(\mathrm{~m}, 1 \mathrm{H}), 1.87$ (br.s, $1 \mathrm{H}), 1.62-1.18(\mathrm{~m}, 18 \mathrm{H}), 1.05(\mathrm{~m}, 3 \mathrm{H})$, $0.84(\mathrm{t}, 3 \mathrm{H}, \mathrm{J}=4.6 \mathrm{~Hz}) ;{ }^{13} \mathrm{C}-\mathrm{NMR}\left(150 \mathrm{MHz}, \mathrm{CDCl}_{3}\right)$ b: 212.0, 156.9, 149.7, 128.3, $127.3,118.4,108.9,63.0,55.3,47.6,44.7,43.5,41.1$, 39.6, 37.8, 31.8, 31.1, 30.00, 29.98, 29.0, 24.7, 22.7, 14.1; MS m/z : $388\left(\mathrm{M}^{+}\right), 303$ (100\%); HRMS Calcd. $\mathrm{C}_{25} \mathrm{H}_{40} \mathrm{O}_{3}$ : 388.2975. Found: 388.2961.

(1R,3R,4R)-3-[4-(1,1-Dimethylheptyl)-2-methoxyphenyl]-4-(3hydroxypropyl)cyclohexanol [(-)-13]: $\mathrm{LiAlH}_{4}(25.4 \mathrm{mg}, 0.669 \mathrm{mmol})$ was 
added to a solution of (3R,4R)-3-[4-(1,1-dimethylheptyl)-2-methoxyphenyl]-4-(3hydroxypropyl)cyclohexanone (105 mg, $0.270 \mathrm{mmol}$ ) in $\mathrm{Et}_{2} \mathrm{O}-\mathrm{THF}(5.0 \mathrm{ml}, 3: 2$ $\mathrm{v} / \mathrm{v}$ ) at $-78^{\circ} \mathrm{C}$ and the mixture was stirred for $3 \mathrm{~h}$ at the same temperature. After warming to room temperature, the mixture was quenched with $\mathrm{H}_{2} \mathrm{O}$ and $3 \mathrm{~N}$ aq. $\mathrm{NaOH}$ and stirring was continued for $30 \mathrm{~min}$ at the same temperature. The mixture was extracted with AcOEt and washed with $\mathrm{H}_{2} \mathrm{O}$. The aqueous layer was extracted with AcOEt and the combined organic solution was washed with brine, dried over $\mathrm{MgSO}_{4}$, and concentrated under reduced pressure. The residue was purified by silica gel column chromatography [hexane-AcOEt $(4: 1-3: 1 \mathrm{v} / \mathrm{v})$ ] to afford diol (-)-13 (89 mg, $84 \%$, equatorial alcohol) and its epimer (13 mg, $12 \%$, axial alcohol) as a colorless oil respectively.

[]$_{D}{ }^{30}=-33.6^{\circ}$ (c 0.42, $\mathrm{CHCl}_{3}$ ); IR (neat): 3350, 1610, $1569 \mathrm{~cm}^{-1} ;{ }^{1} \mathrm{H}-\mathrm{NMR}$ (600 $\mathrm{MHz}, \mathrm{CDCl}_{3}$ ) b: $7.03(\mathrm{~d}, 1 \mathrm{H}, J=5.0 \mathrm{~Hz}), 6.86(\mathrm{~d}, 1 \mathrm{H}, J=4.6 \mathrm{~Hz}), 6.79(\mathrm{~s}, 1 \mathrm{H})$, $3.79(\mathrm{~s}, 3 \mathrm{H}), 3.70(\mathrm{~m}, 1 \mathrm{H}), 3.43(\mathrm{~m}, 2 \mathrm{H}), 2.87$ (br.s, $1 \mathrm{H}), 2.05(\mathrm{~m}, 1 \mathrm{H}), 1.97(\mathrm{~m}$, $2 \mathrm{H}), 1.60-1.02(\mathrm{~m}, 25 \mathrm{H}), 0.90(\mathrm{~m}, 1 \mathrm{H}), 0.84(\mathrm{t}, 3 \mathrm{H}, J=4.6 \mathrm{~Hz}) ;{ }^{13} \mathrm{C}-\mathrm{NMR}(150$ $\mathrm{MHz}, \mathrm{CDCl}_{3}$ ) b:156.8, 148.8, 129.9, 126.1, 118.3, 108.7, 70.9, 63.2, 55.5, 44.6, 43.6, 40.6, 38.5, 37.6, 35.5, 31.6, 30.1, 29.9, 29.7, 28.90, 28.88, 24.6, 22.5, 14.0; MS m/z : $390\left(\mathrm{M}^{+}\right), 390(100 \%)$; HRMS Calcd. $\mathrm{C}_{25} \mathrm{H}_{42} \mathrm{O}_{3}: 390.3132$. Found: 390.3137 .

CP 55,940 [(-)-3]: $1.6 \mathrm{M} \mathrm{n}$-BuLi in hexane (1.25 ml, $2.0 \mathrm{mmol})$ was added dropwisely to a solution of $1-\mathrm{PrSH}(0.300 \mathrm{ml}, 3.31 \mathrm{mmol})$ in hexamethylphosphoric triamide $(3.0 \mathrm{ml})$ at $0{ }^{\circ} \mathrm{C}$ and the mixture was stirred for $10 \mathrm{~min}$ at the same temperature. The mixture was further stirred for $10 \mathrm{~min}$ at room temperature. Then, the whole mixture was added to aryl methyl ether (-)13 (12 $\mathrm{mg}, 0.031 \mathrm{mmol}$ ) in another flask at room temperature. The reaction mixture was heated to $100-120^{\circ} \mathrm{C}$ and stirred for $5 \mathrm{~h}$ at the same temperature. After cooling, the mixture was quenched with saturated aqueous $\mathrm{NH}_{4} \mathrm{Cl}$, extracted with AcOEt and washed with $\mathrm{H}_{2} \mathrm{O}$. The aqueous layer was extracted with AcOEt several times and the combined organic extract was washed with brine, dried over $\mathrm{MgSO}_{4}$, and concentrated under reduced pressure. The residue was purified by silica gel column chromatography [hexane-AcOEt (3:2-1:1 v/v)] to afford CP 55,940 [(-)-3] (10.4 mg, $90 \%)$ as a white solid. 
$\mathrm{mp} 65-68{ }^{\circ} \mathrm{C} ; \mathrm{L}_{\mathrm{D}}{ }^{29}=-28.2^{\circ}\left(\mathrm{c} 0.15, \mathrm{CHCl}_{3}\right.$ ) [an authentic sample purchased from TOCRIS Co., Ltd. $\mathrm{C}_{24} \mathrm{H}_{40} \mathrm{O}_{3} \mathrm{u} / 2 \mathrm{H}_{2} \mathrm{O}$ : [_] ${ }_{\mathrm{D}}^{33}=-27.7^{\circ}$ (c $0.20, \mathrm{CHCl}_{3}$ )]; IR (neat): $3338,1578 \mathrm{~cm}^{-1}$; ${ }^{1} \mathrm{H}-\mathrm{NMR}\left(600 \mathrm{MHz}, \mathrm{CD}_{3} \mathrm{OD}\right)$ b: 7.01 (br.s, $\left.1 \mathrm{H}\right), 6.74$ (br.s, 1H), 3.62 (br.s, 1H), $3.33(\mathrm{~m}, 2 \mathrm{H}), 2.89$ (br.s, 1H), $2.01(\mathrm{~m}, 3 \mathrm{H}), 1.55(\mathrm{~m}, 3 \mathrm{H})$, 1.40-0.90 (m, 21H), $0.85(\mathrm{t}, 3 \mathrm{H}, J=4.8 \mathrm{~Hz}) ;{ }^{13} \mathrm{C}-\mathrm{NMR}\left(150 \mathrm{MHz}, \mathrm{CD}_{3} \mathrm{OD}\right)$ b:155.4, 149.4, 129.5, 127.4, 118.4, 114.0, 71.7, 63.6, 45.7, 44.7, 42.4, 39.7, 38.2, 36.4, 32.9, 31.3, 31.1, 30.9, 30.6, 29.5, 25.8, 23.6, 14.4; MS m/z : $376\left(\mathrm{M}^{+}\right)$, 273 (100\%); HRMS Calcd. $\mathrm{C}_{24} \mathrm{H}_{40} \mathrm{O}_{3}: 376.2975$. Found: 376.2971.

These spectral data were identical with those of a commercially available CP 55,940 from TOCRIS Co., Ltd.

\section{References}

(1) (a) Frigerio, M.; Santagostino, M.; Sputore, S. J. Org. Chem. 1999, 64, 4537.(b) Nicolaou, K. C.; Zhong, Y.-L.; Baran, P. S. J. Am. Chem. Soc. 2000, 122, 7596. (c) Nicolaou, K. C.; Montagnon, T.; Baran, P. S. Angew. Chem. Int. Ed. 2002, 41, 993.

(2) Mori, K.; Takayama, S.; Kido, M. Bioorg. Med. Chem. 1994, 2, 395.

(3) (a) Remuzon, P.; Massoudi, M.; Bouzard, D.; Jacquet, J.-P. Heterocycles 1992, 34, 679. (b) Rumuzon, P.; Bouzard, D.; Guiol, C.; Jacquet, J.-P. J. Med. Chem. 1992, 35, 2898.

(4) Saa, J. M.; Dopico, M.; Martorell, G.; Raso, A. G.- J. Org. Chem. 1990, 55, 991. 


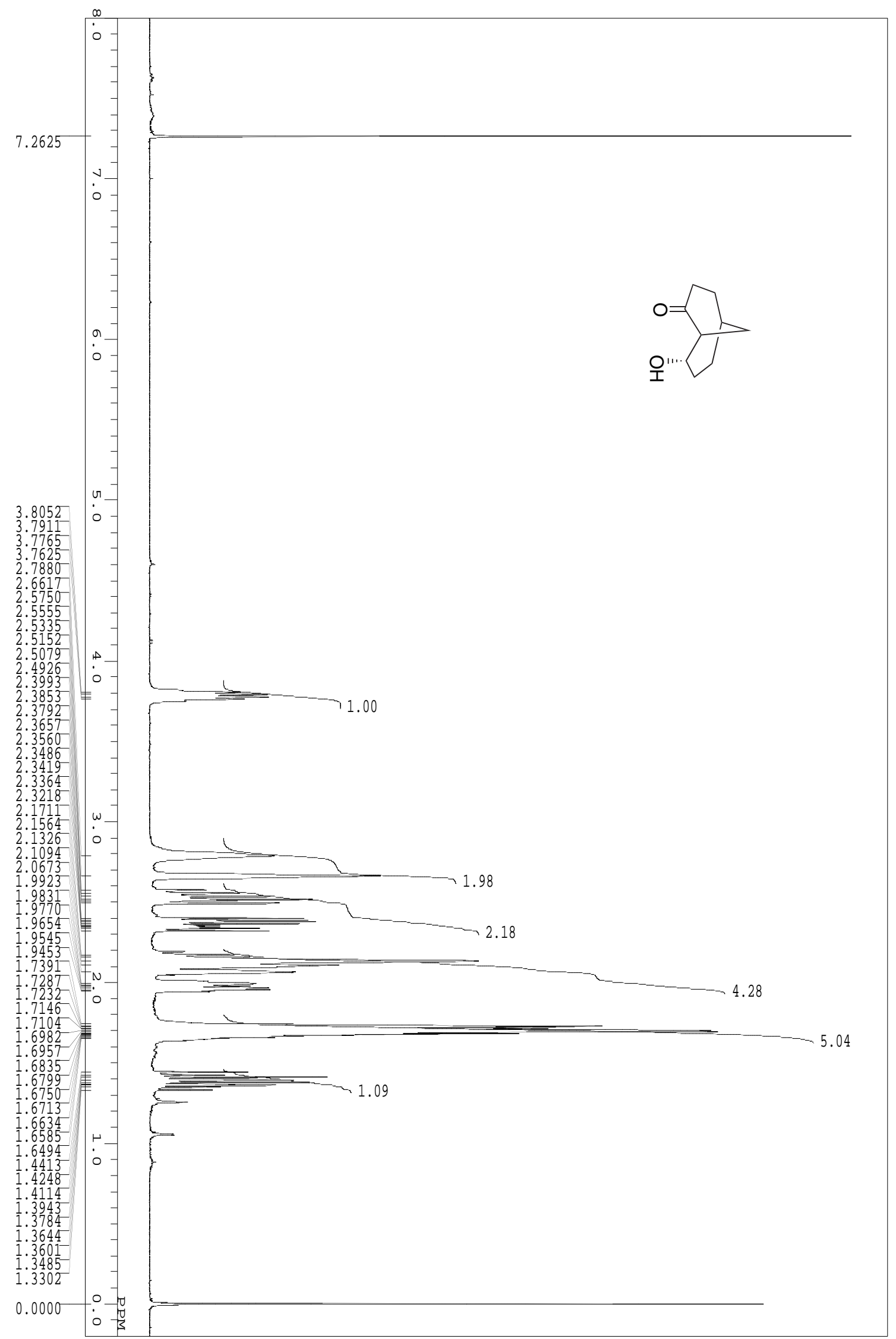

S-14 


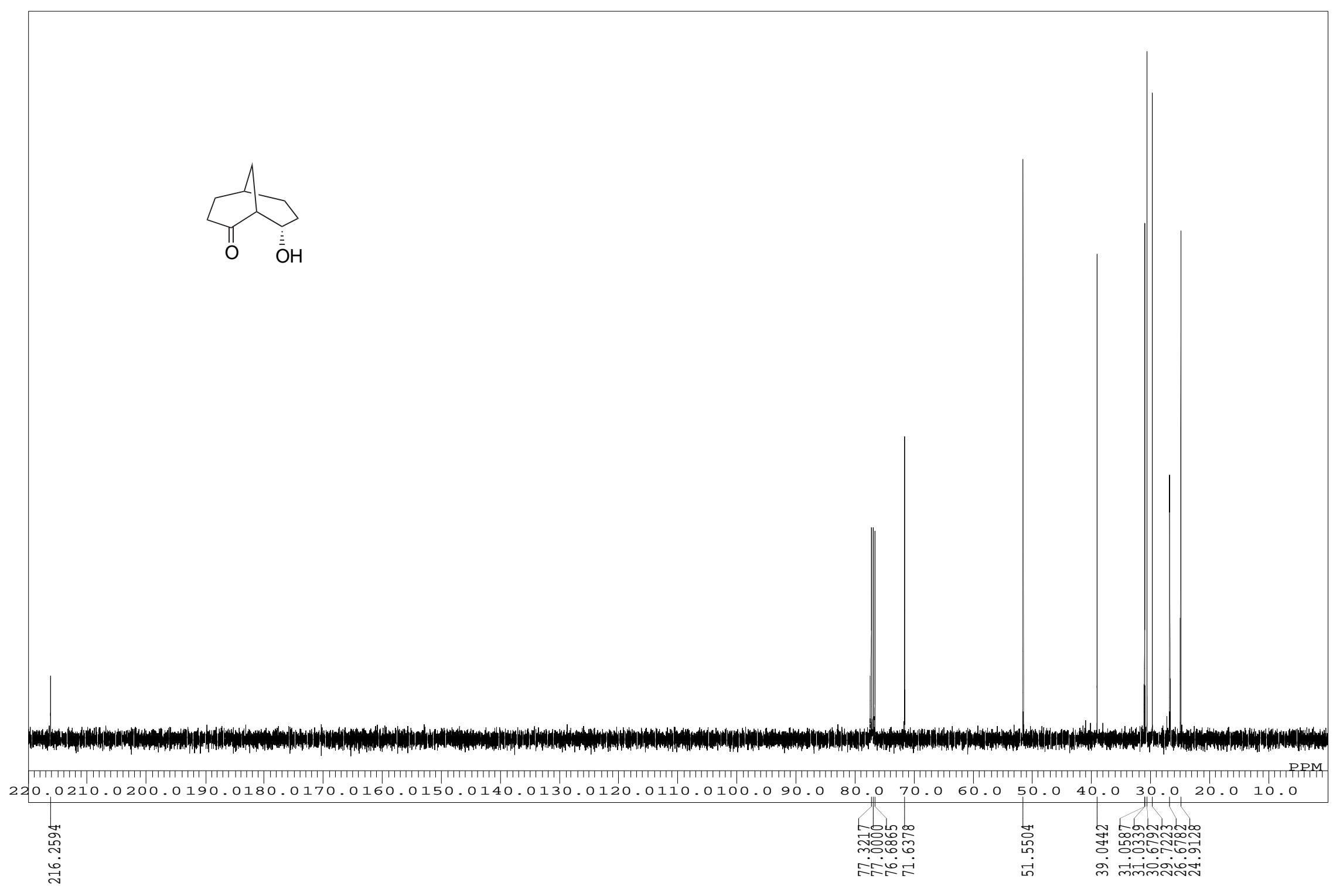




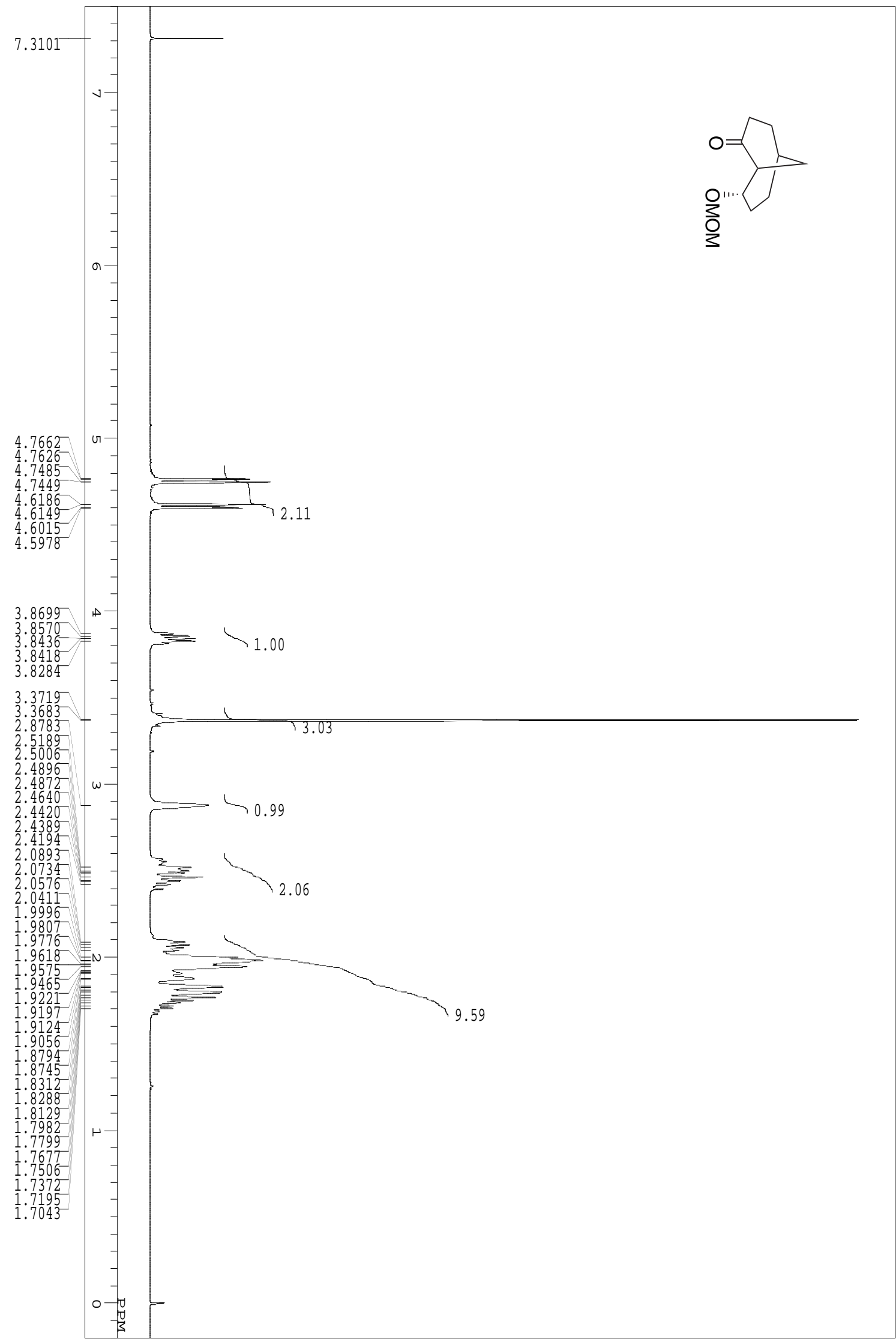




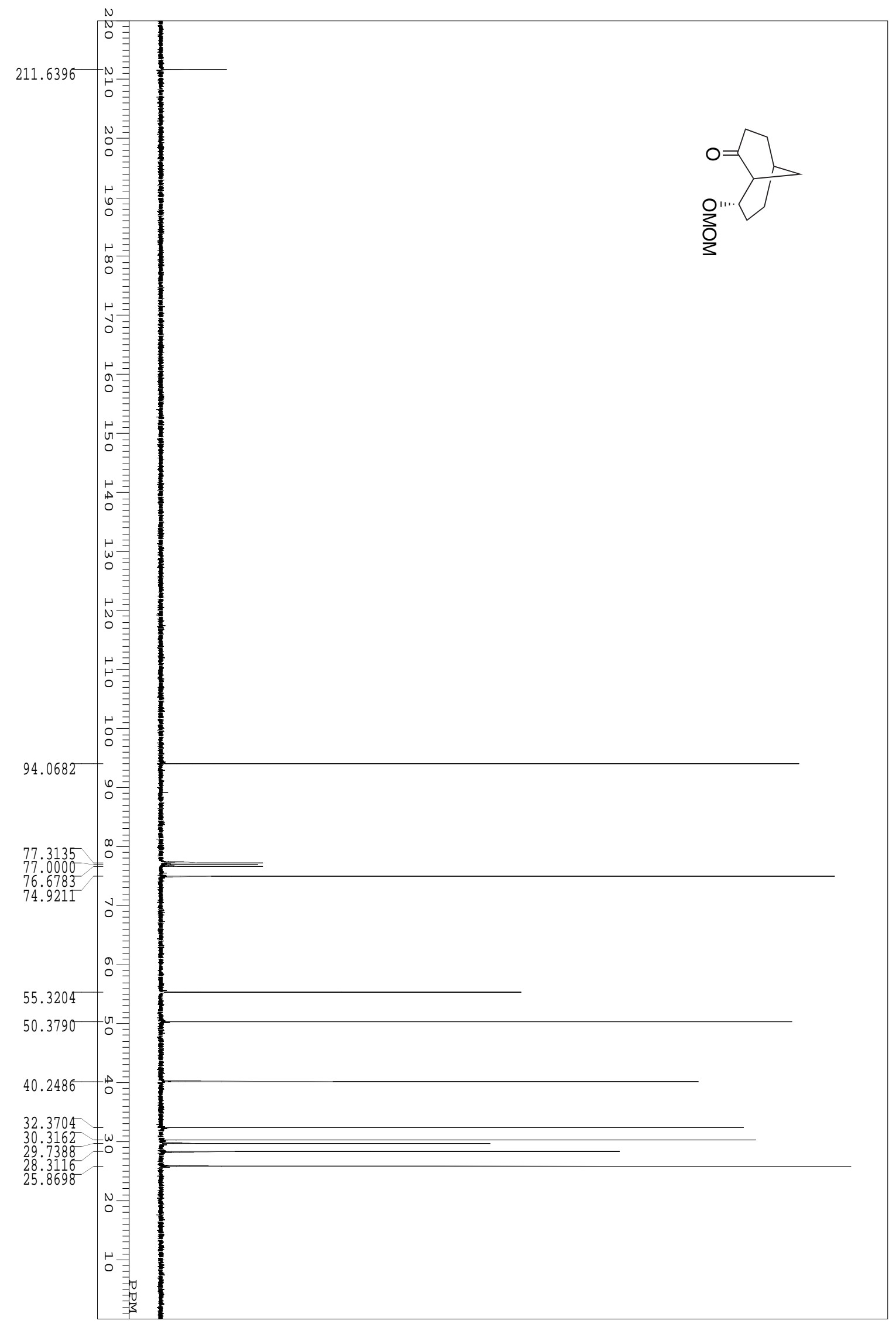

S-17 


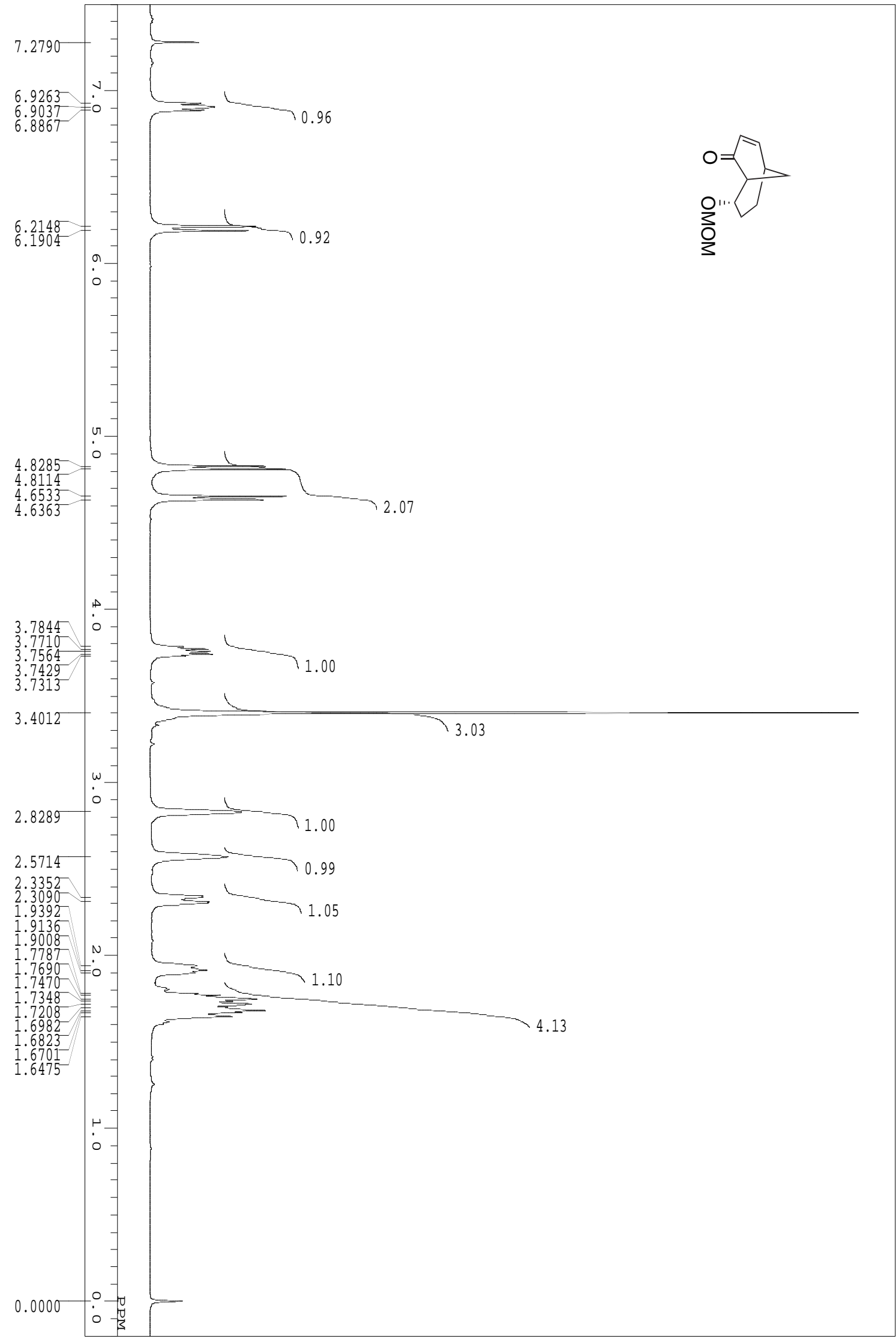




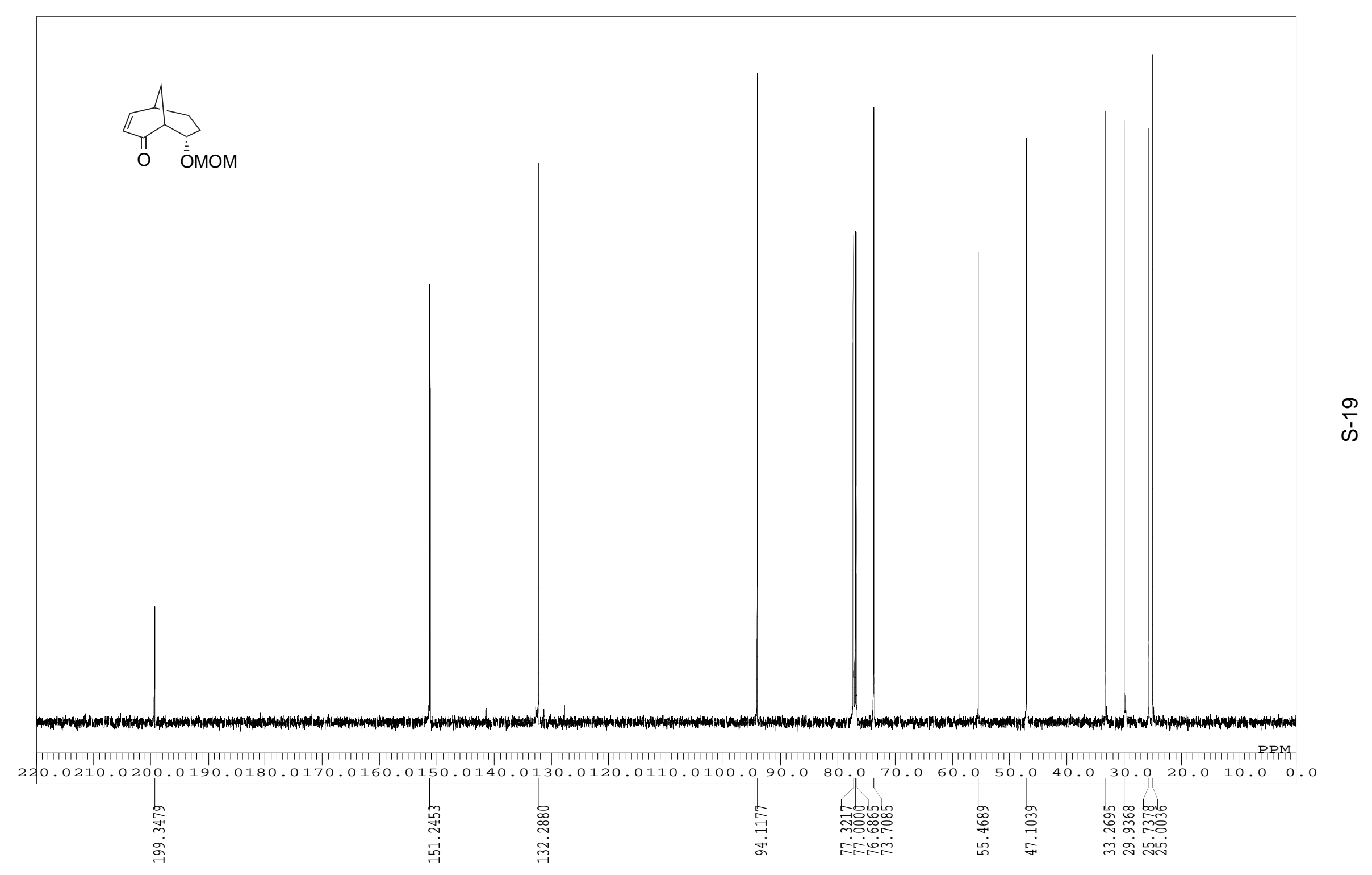




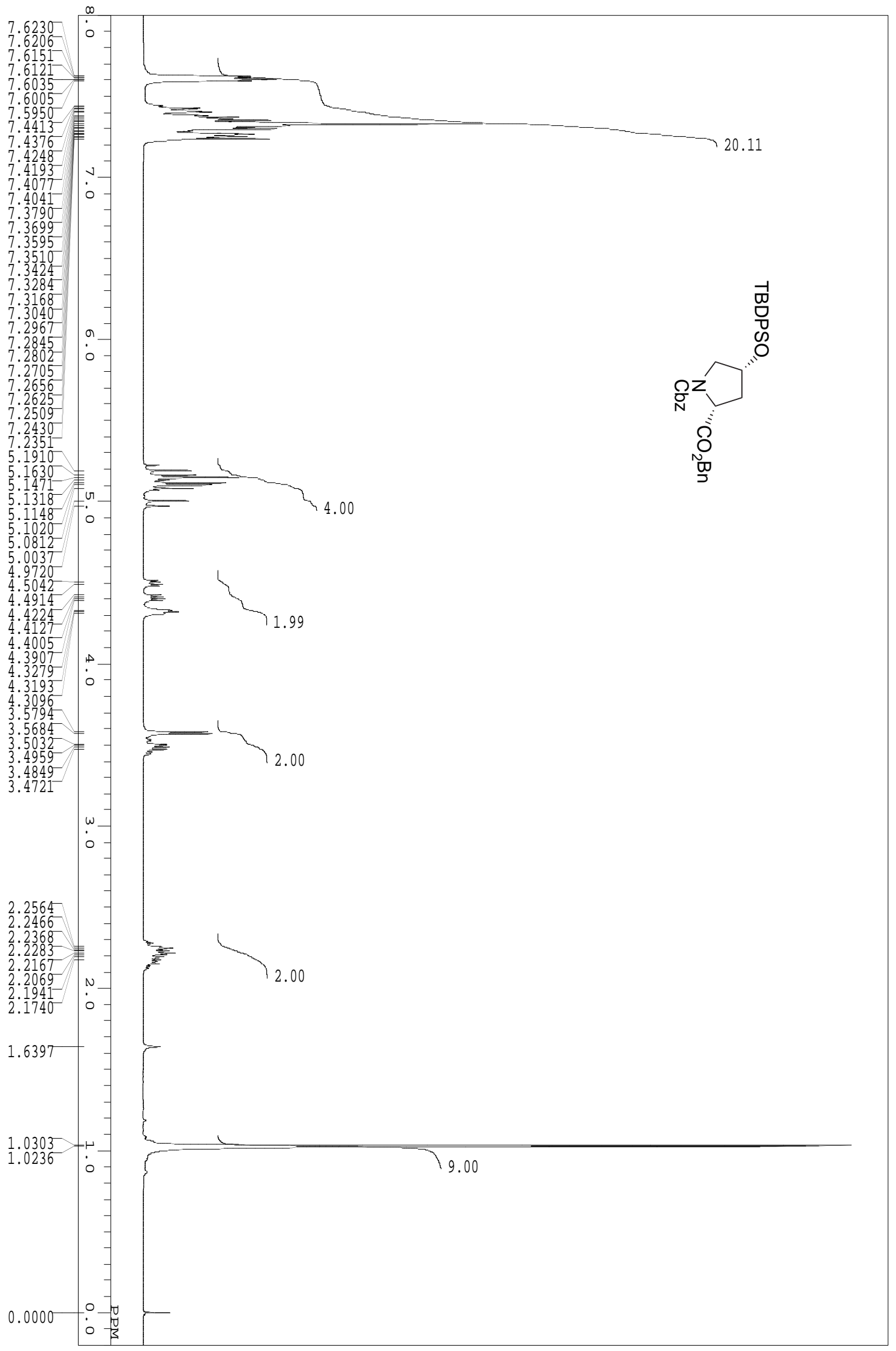




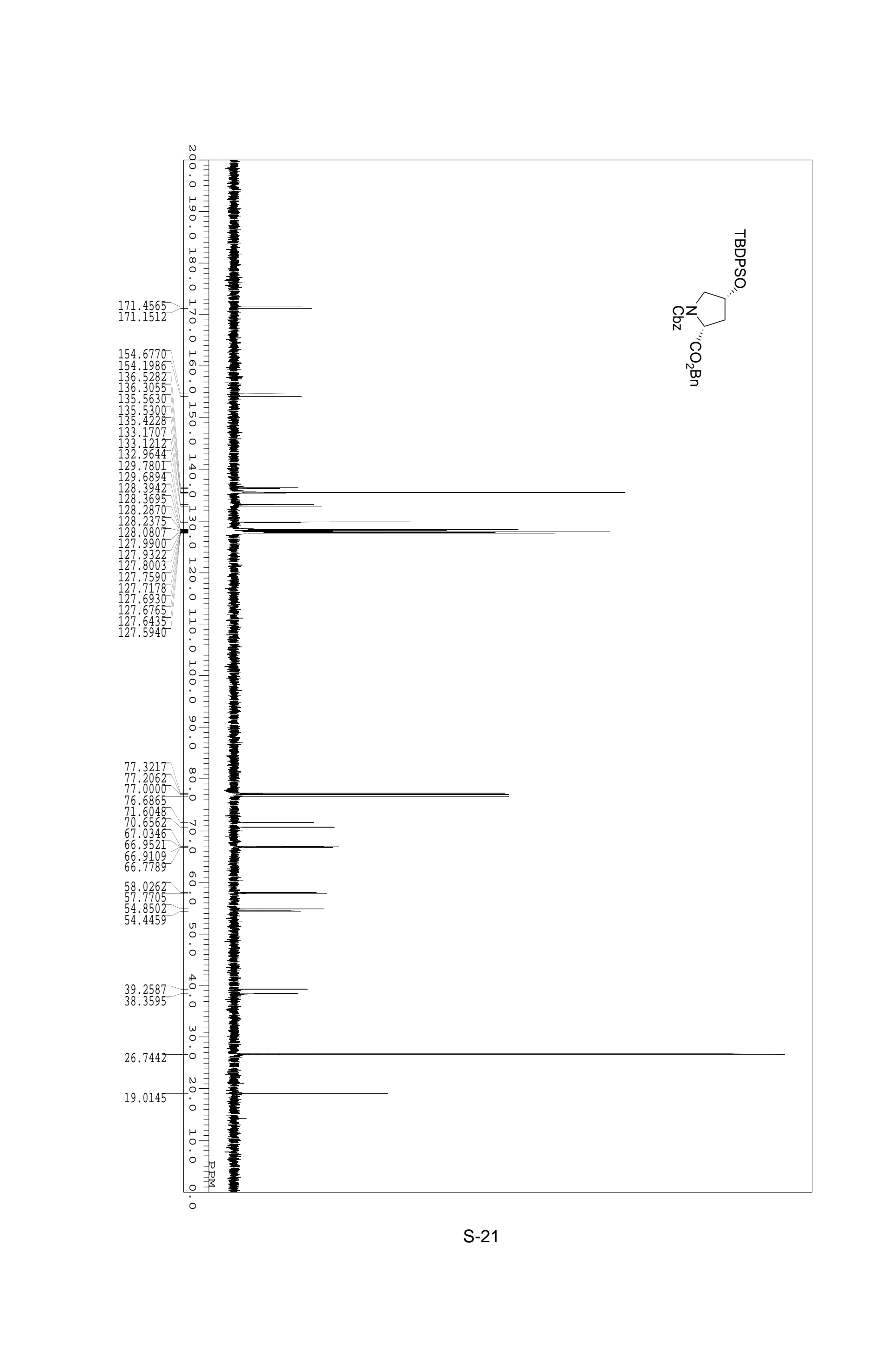




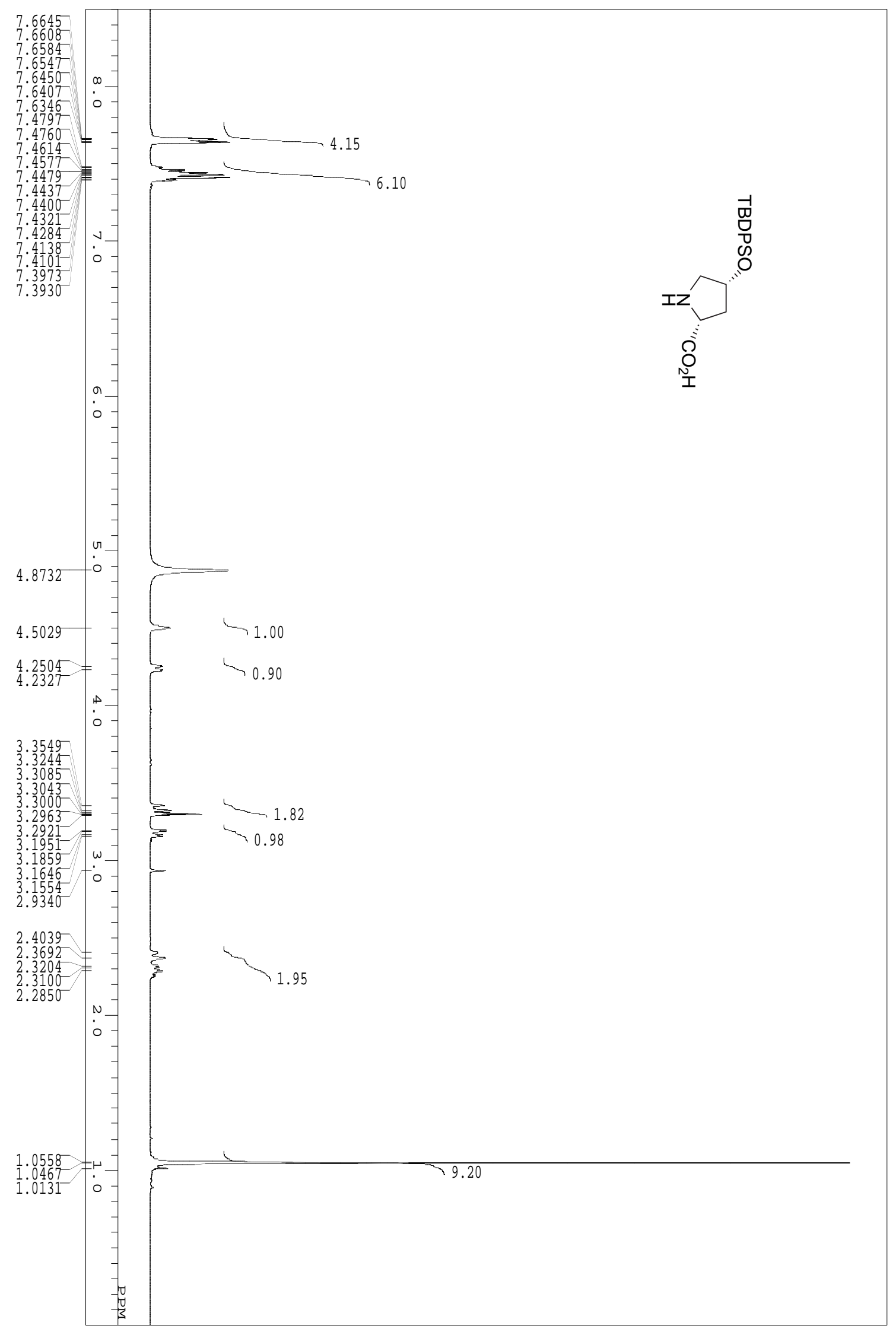




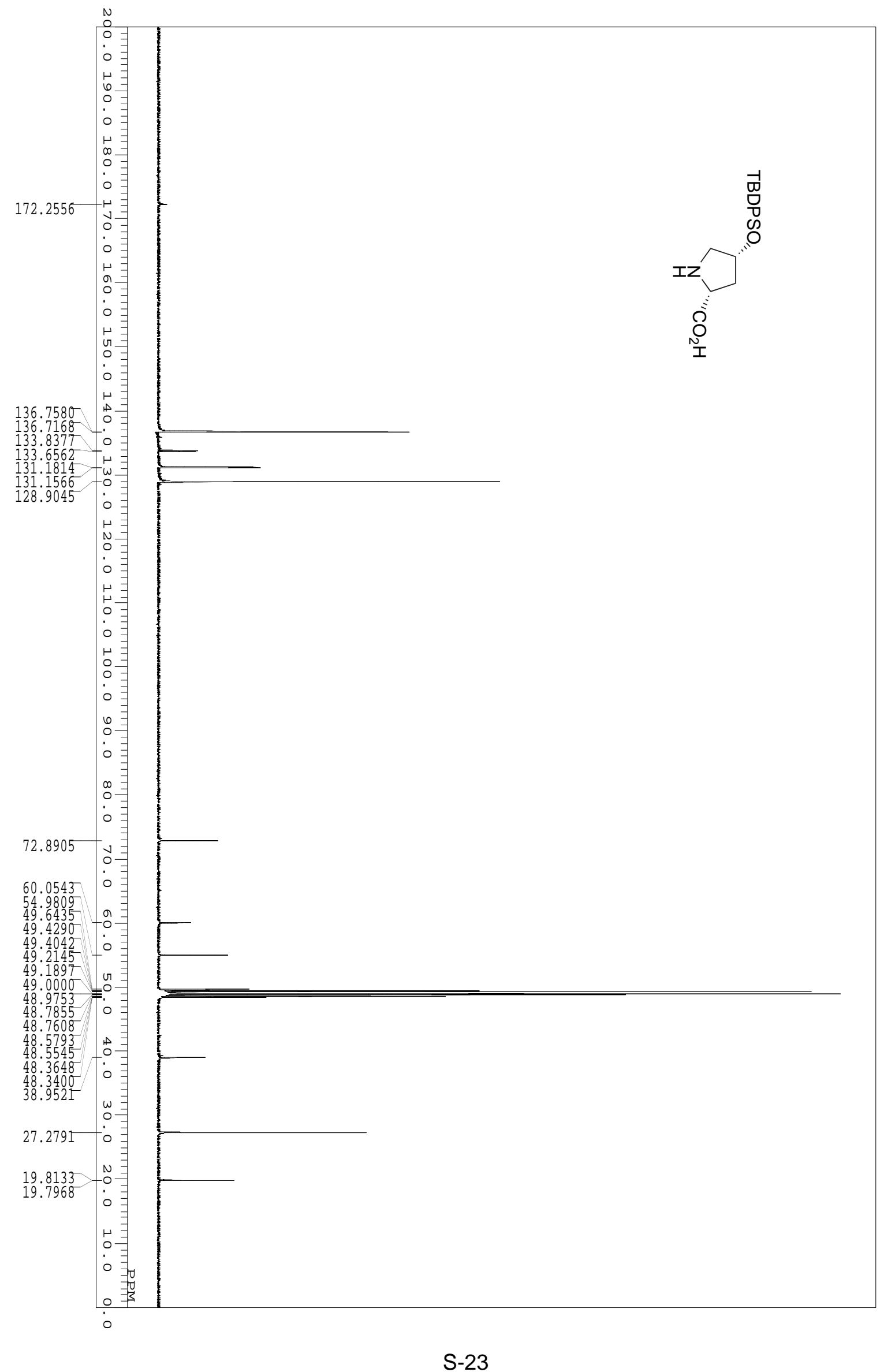




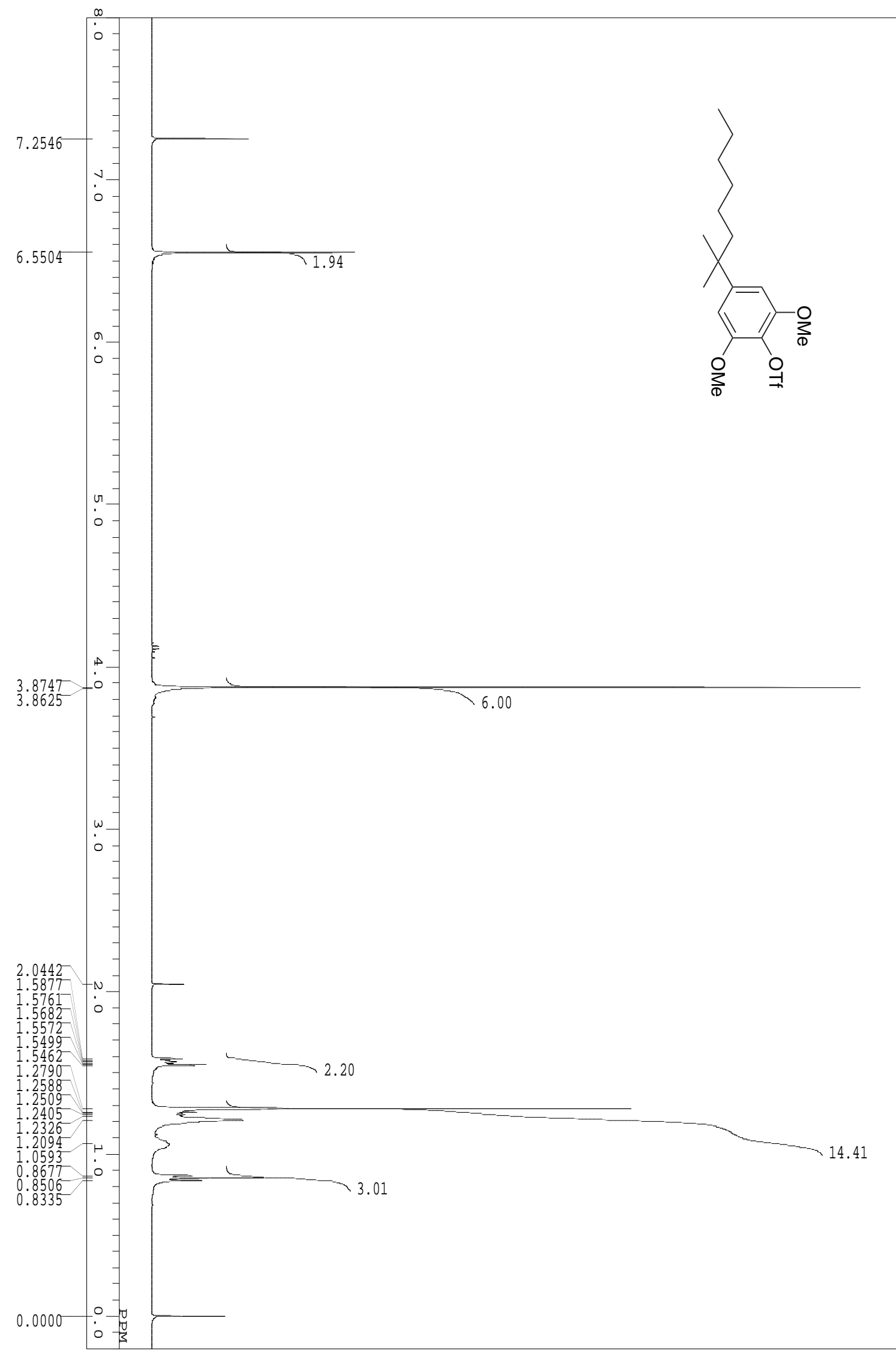




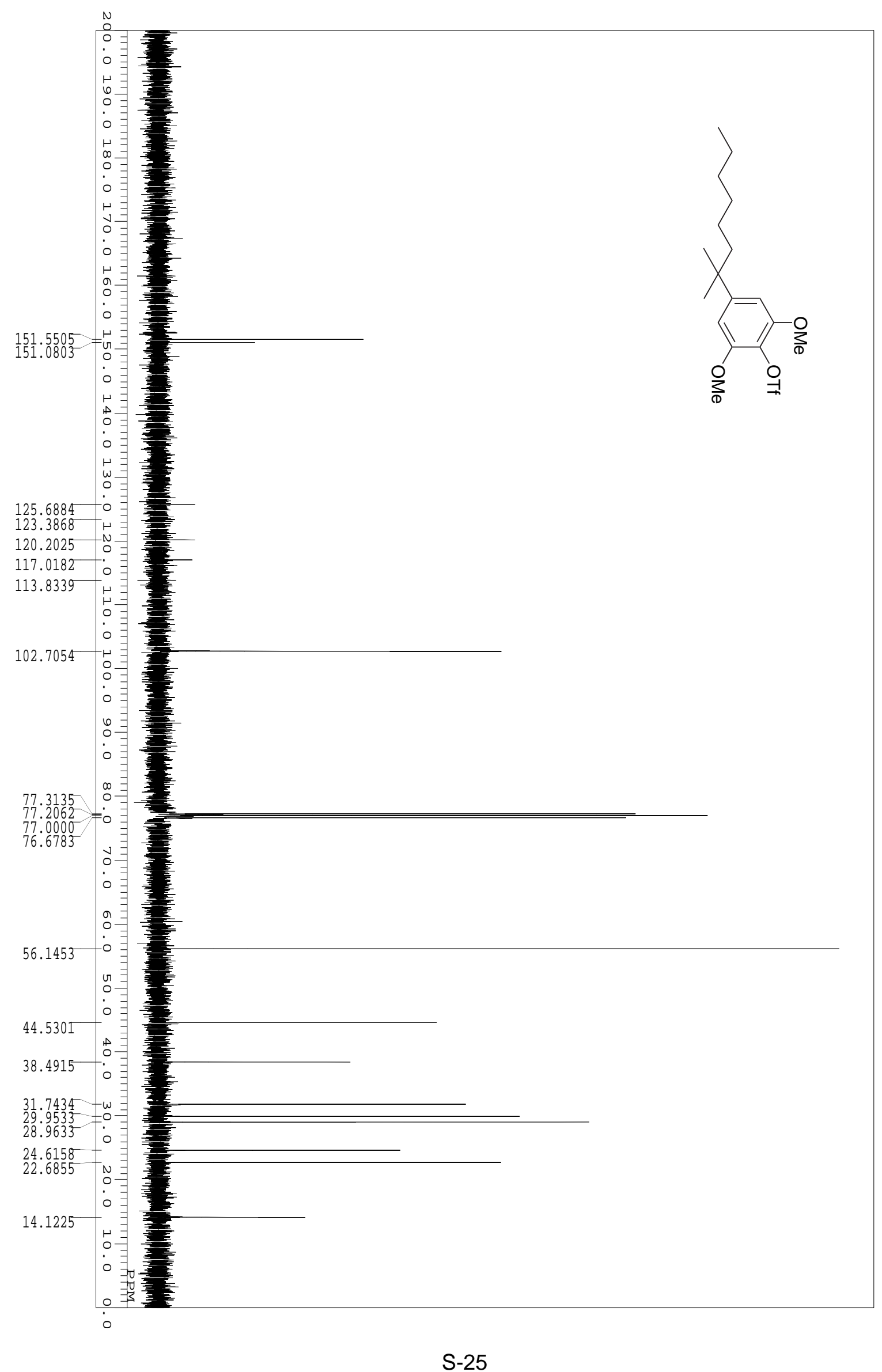




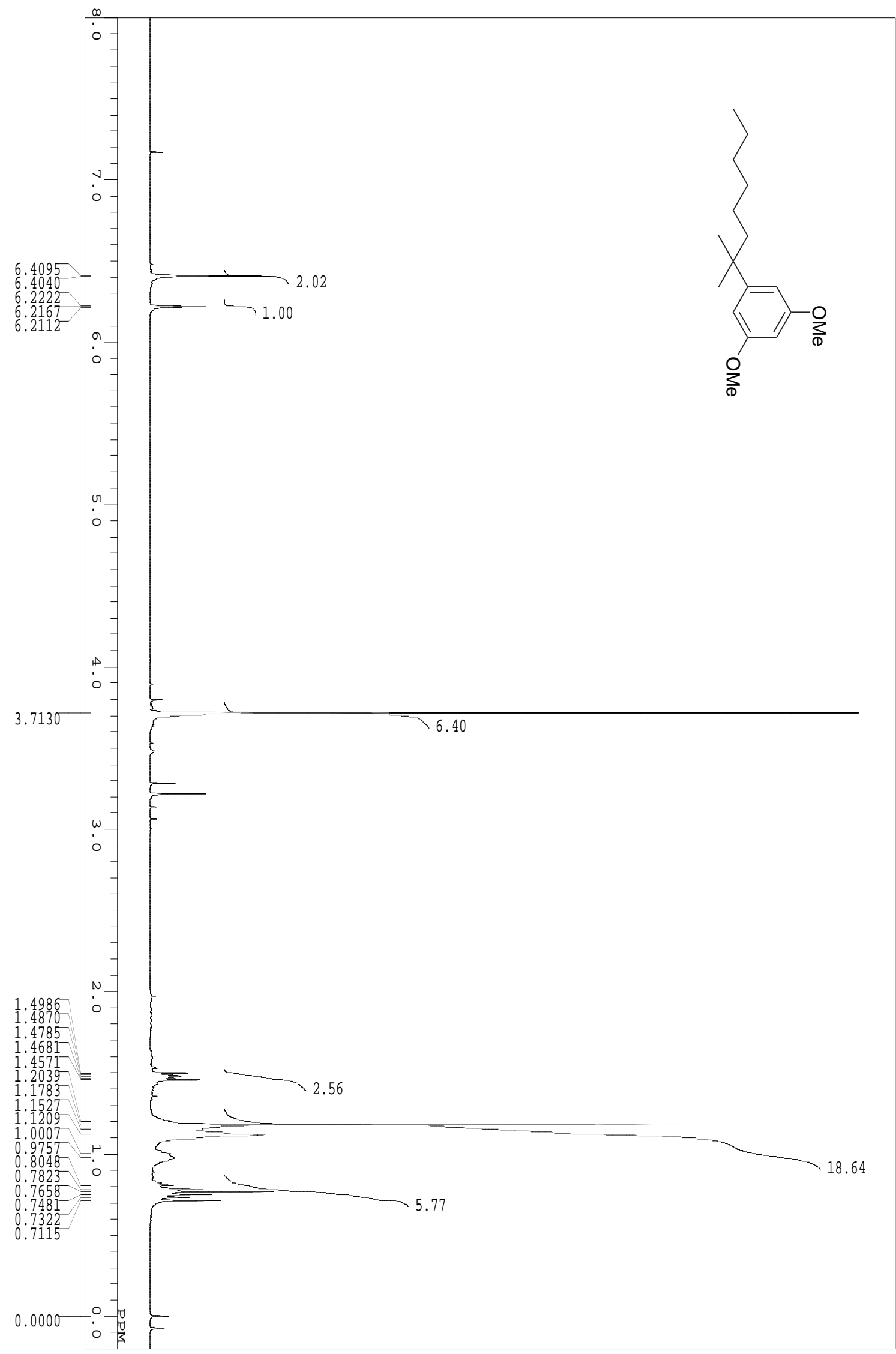




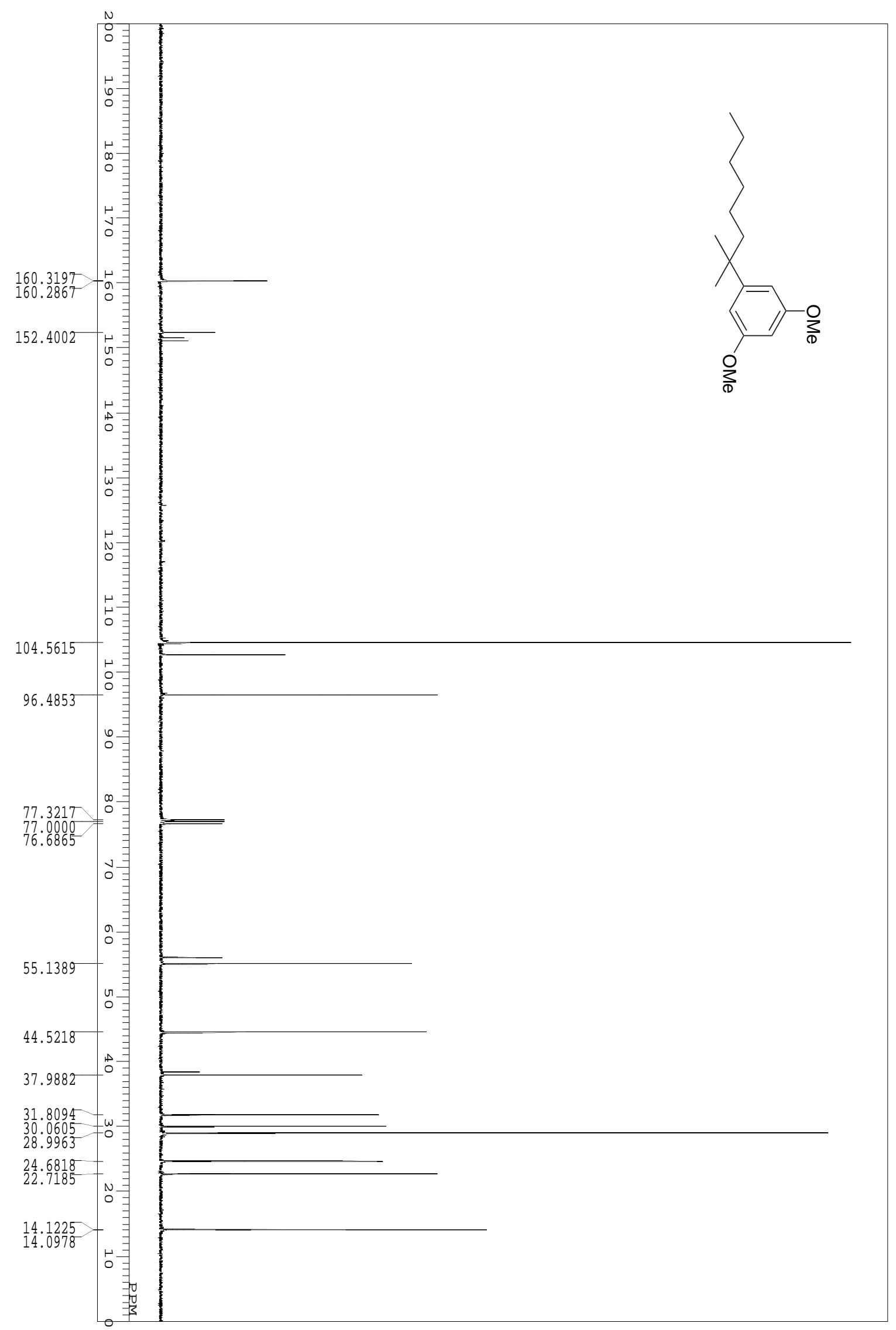

S-27 


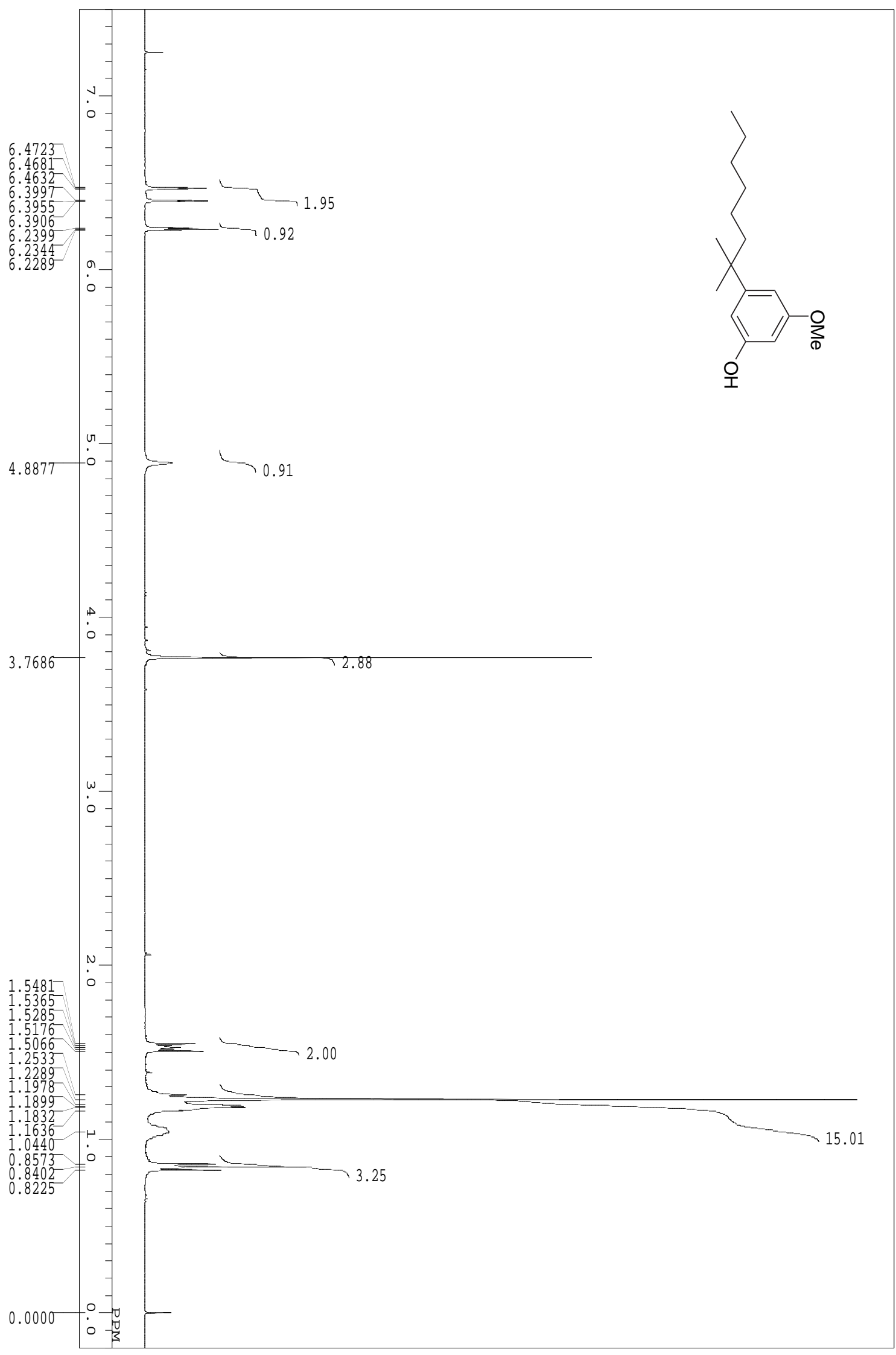




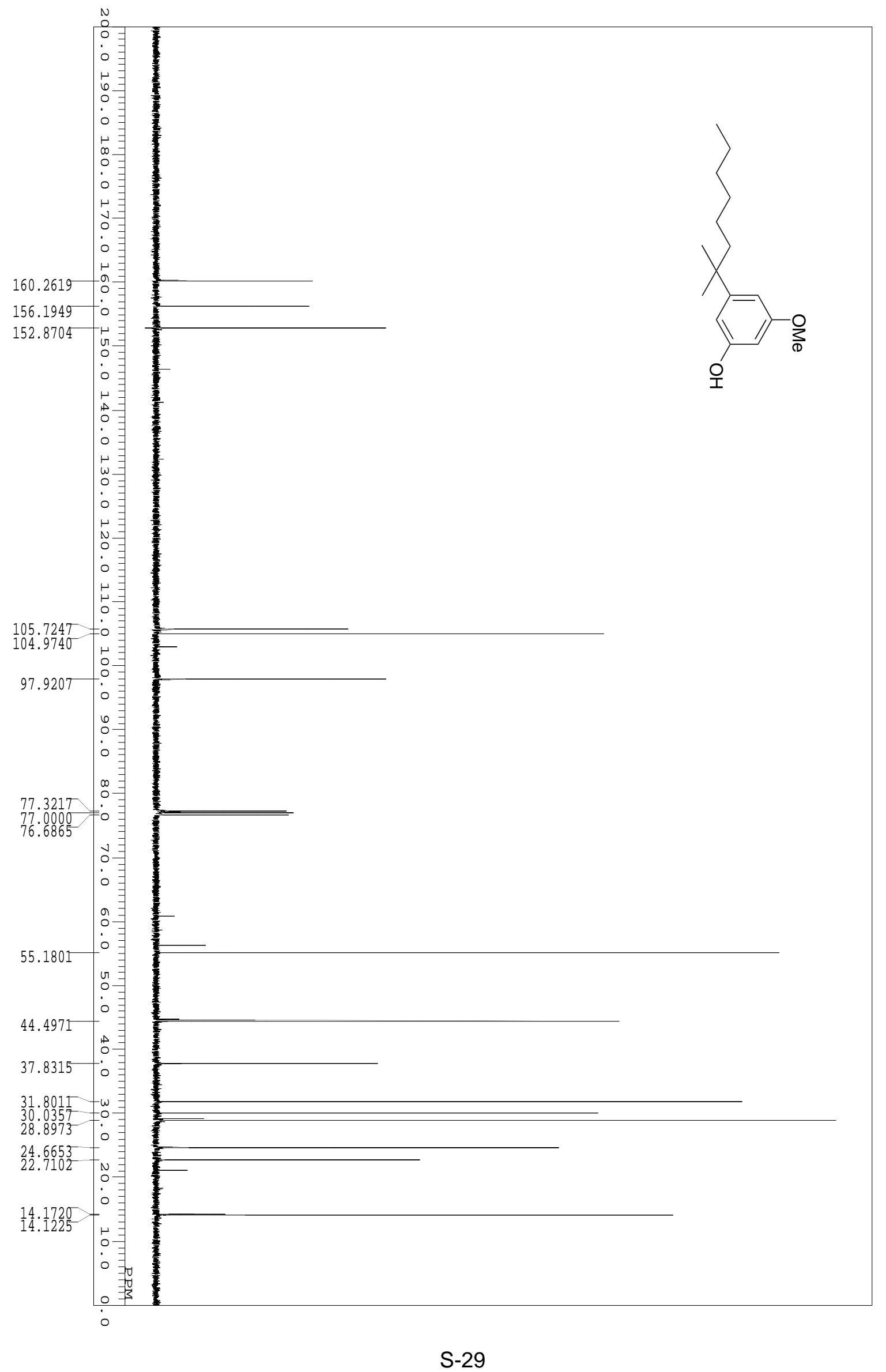



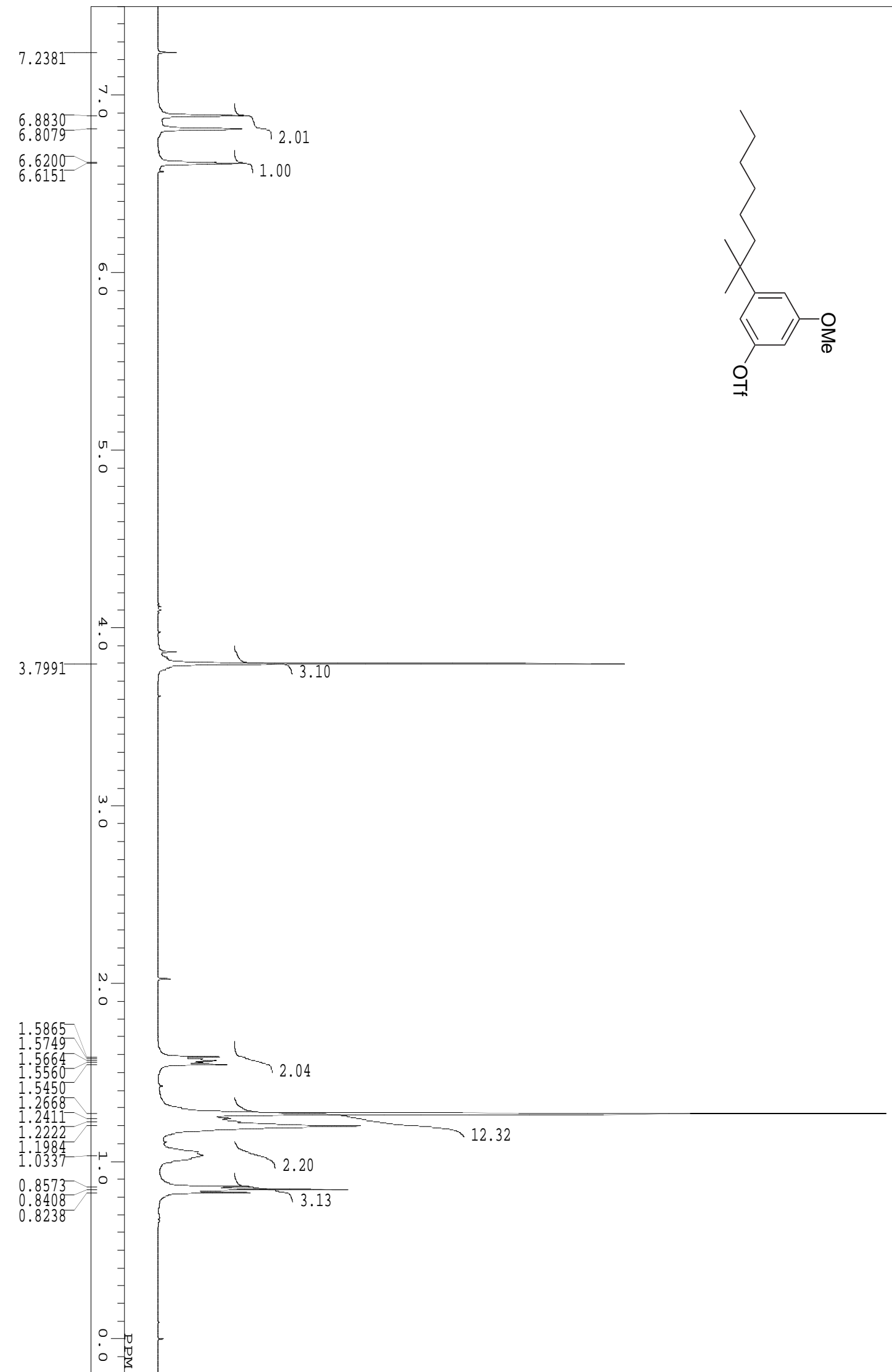


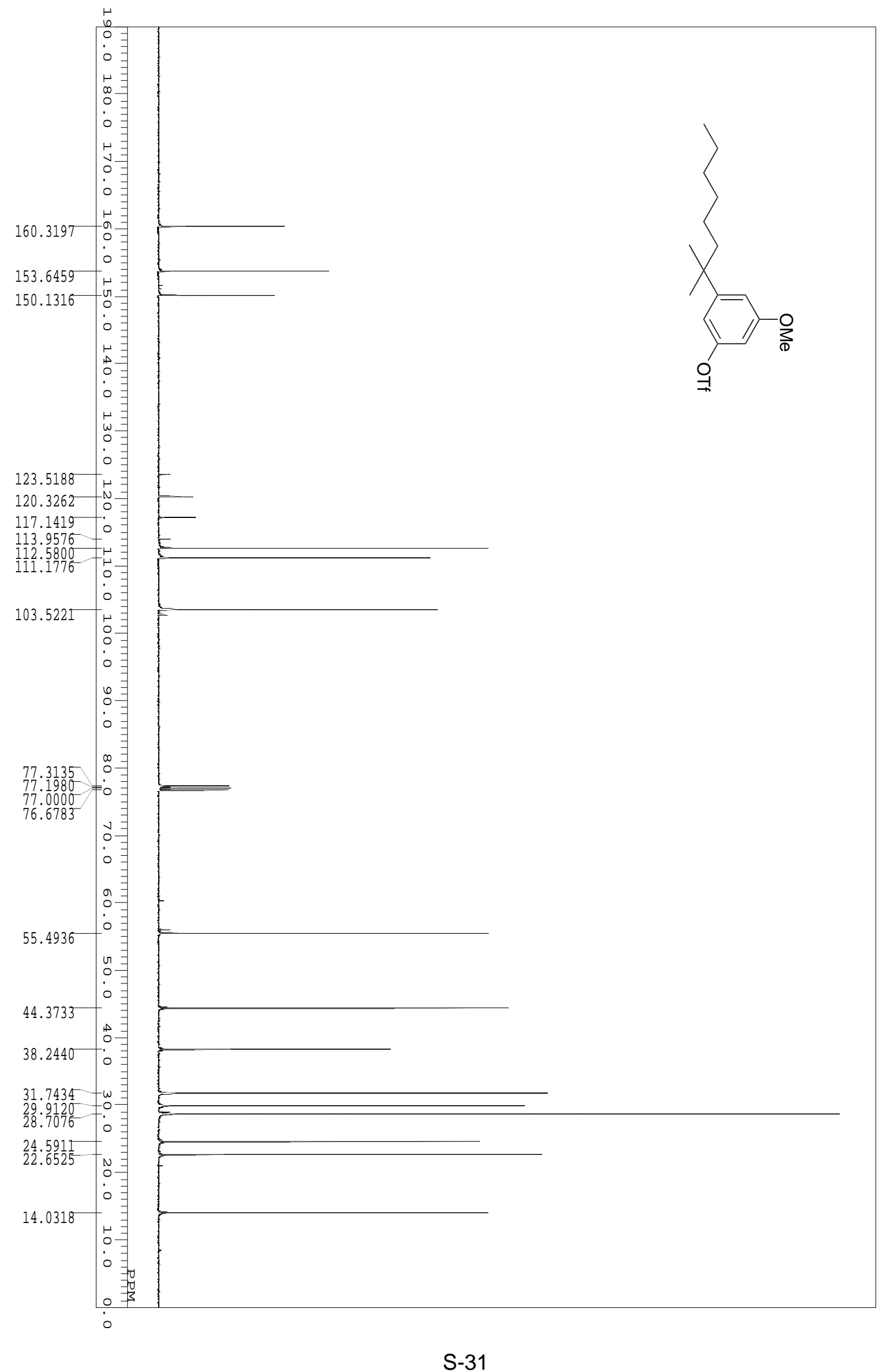




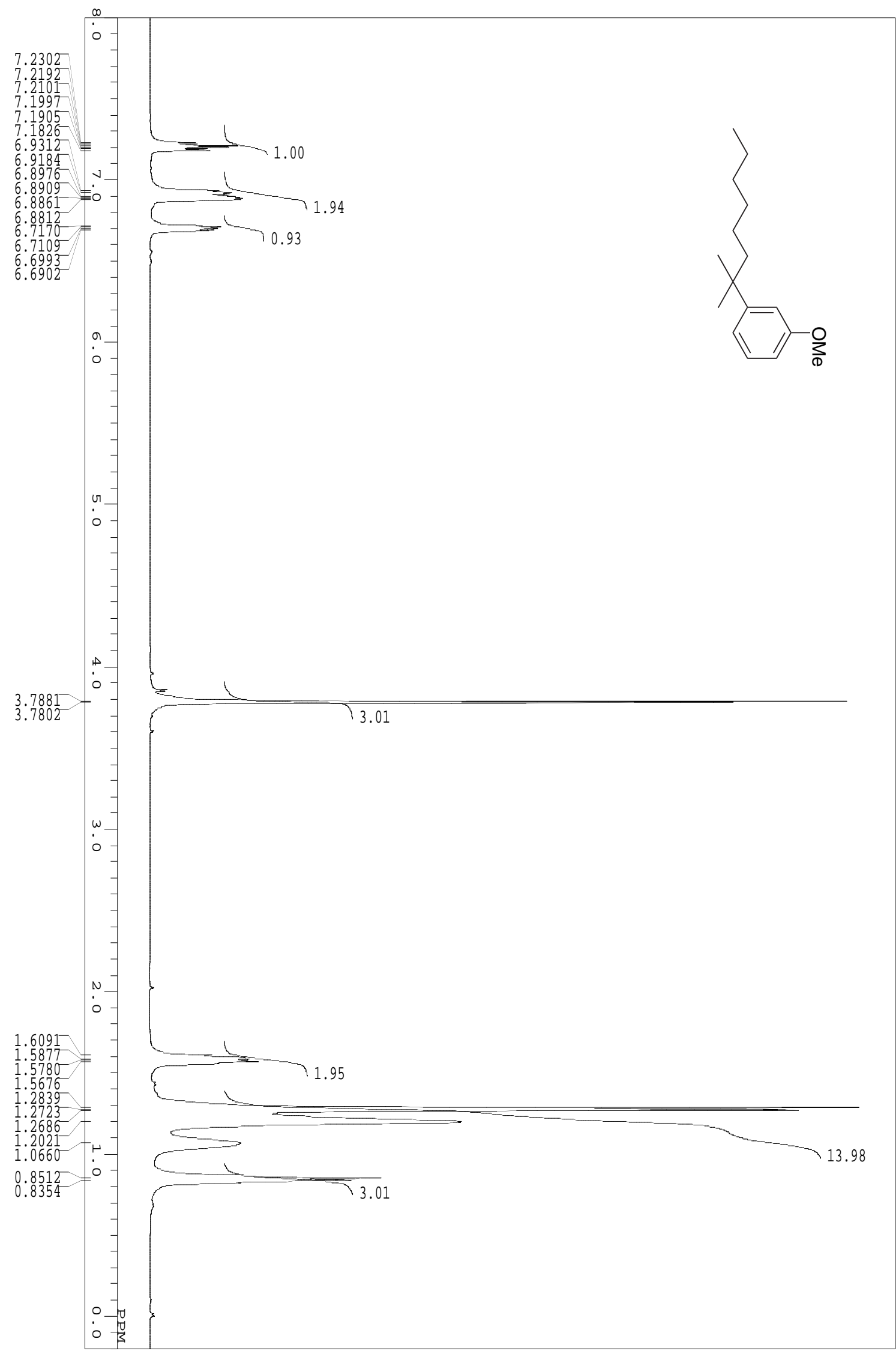




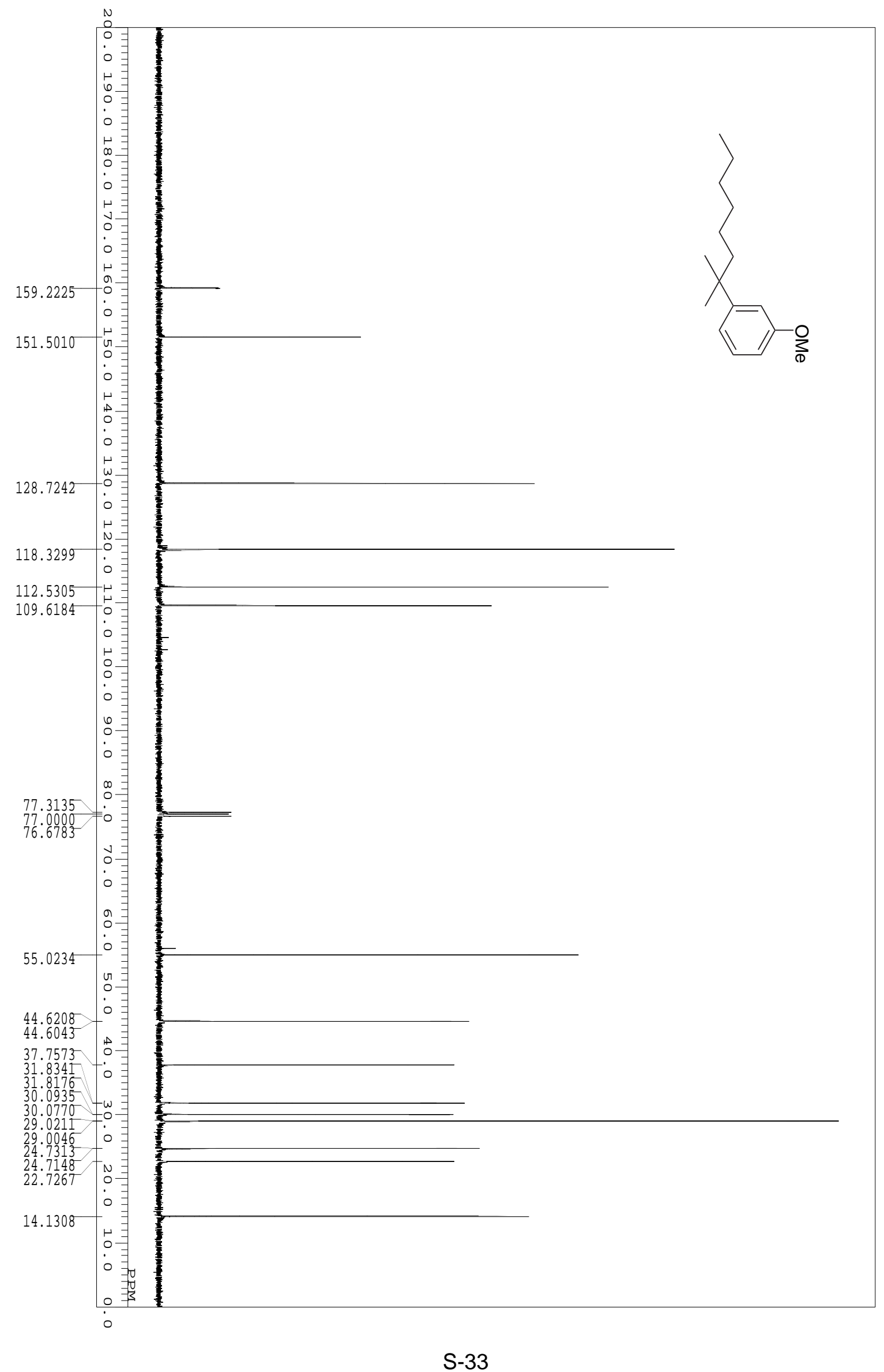




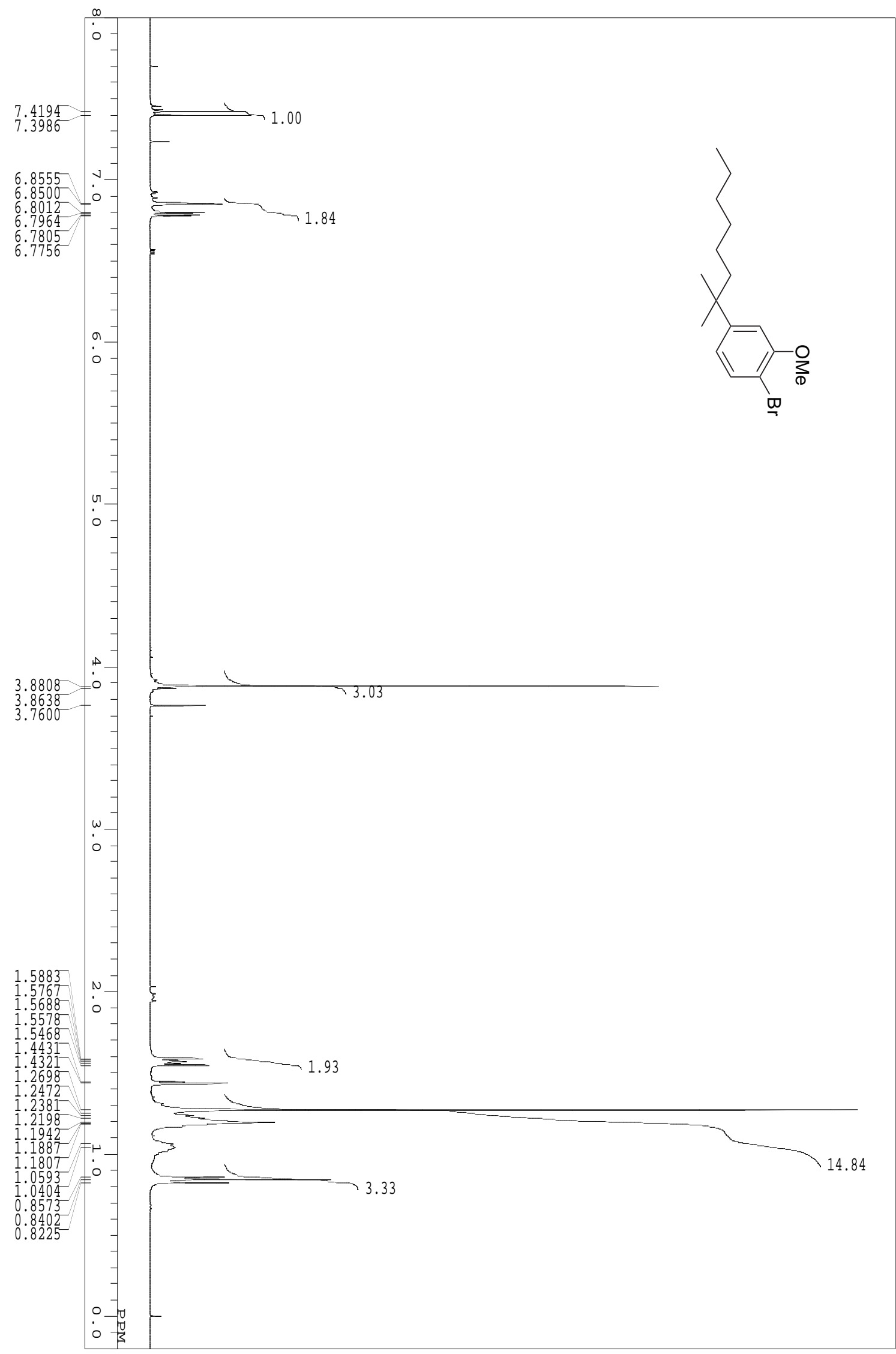




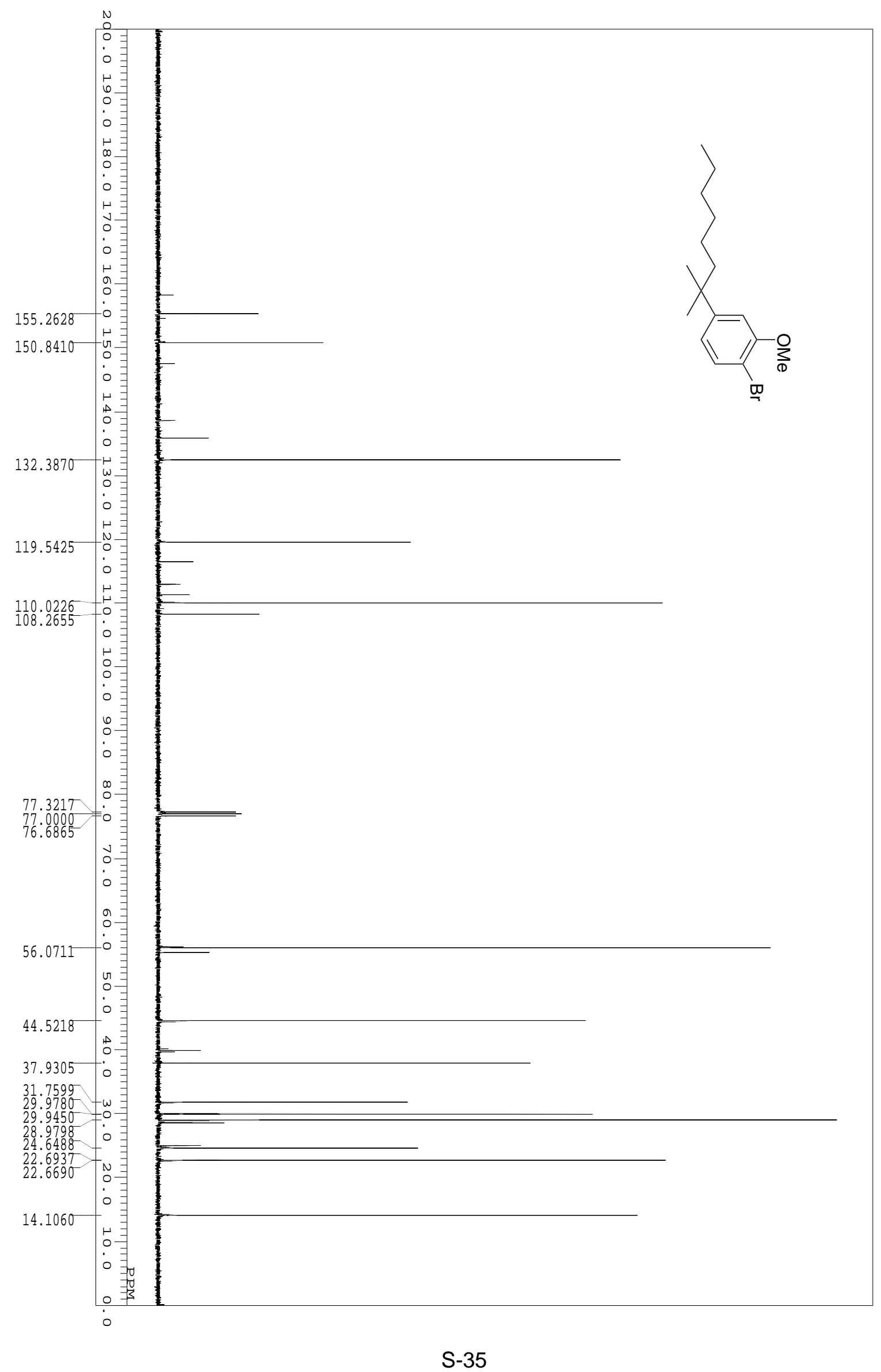




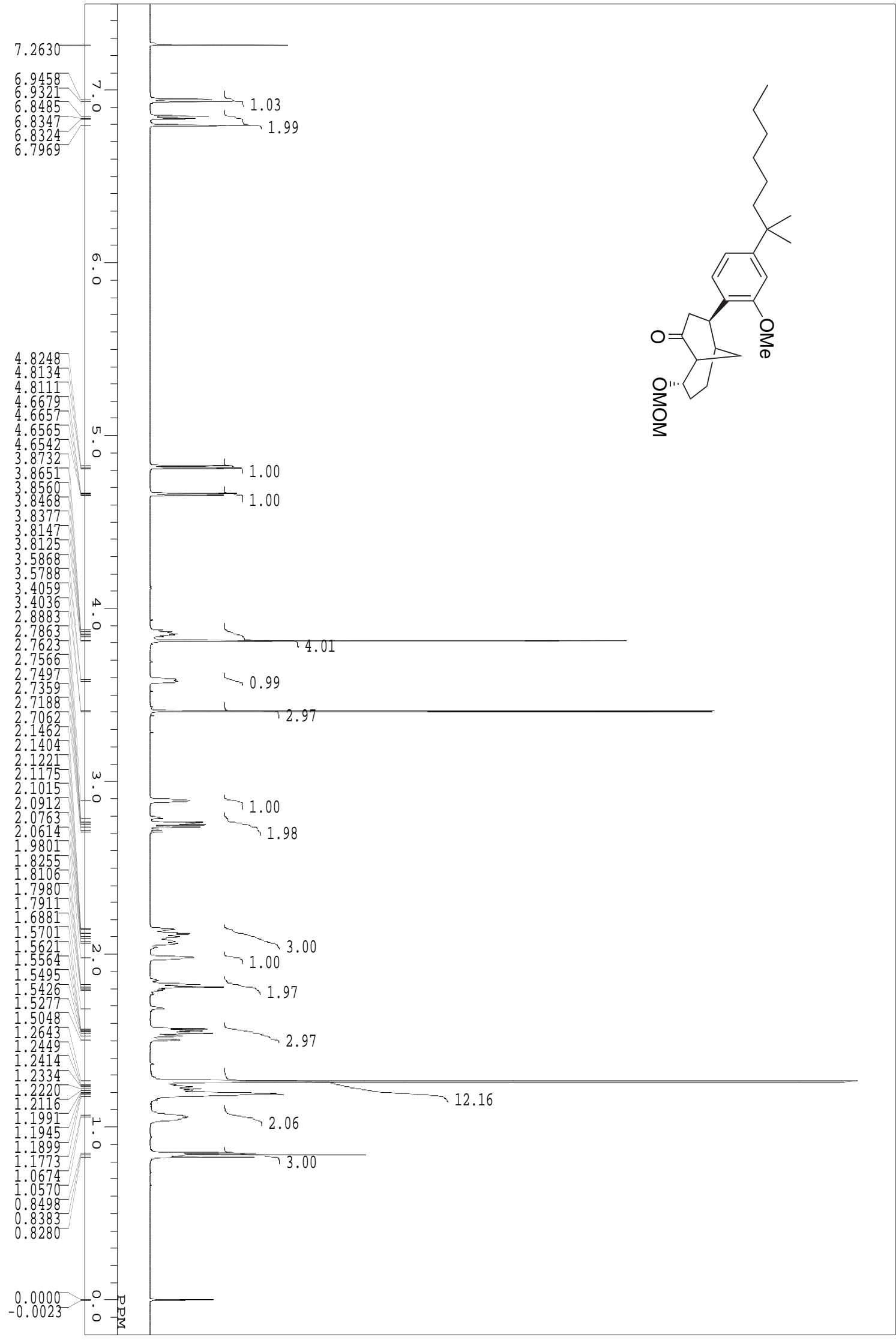




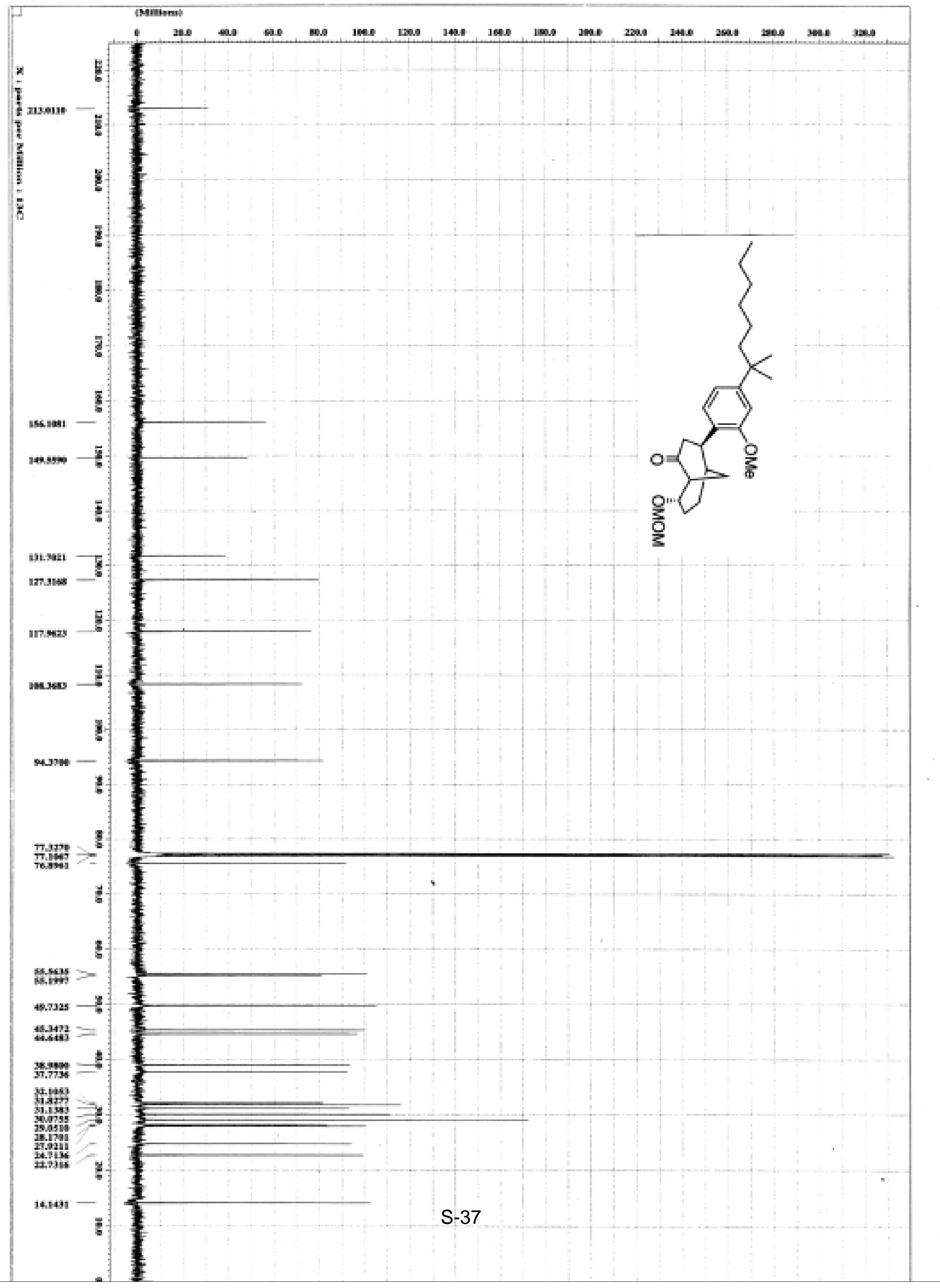




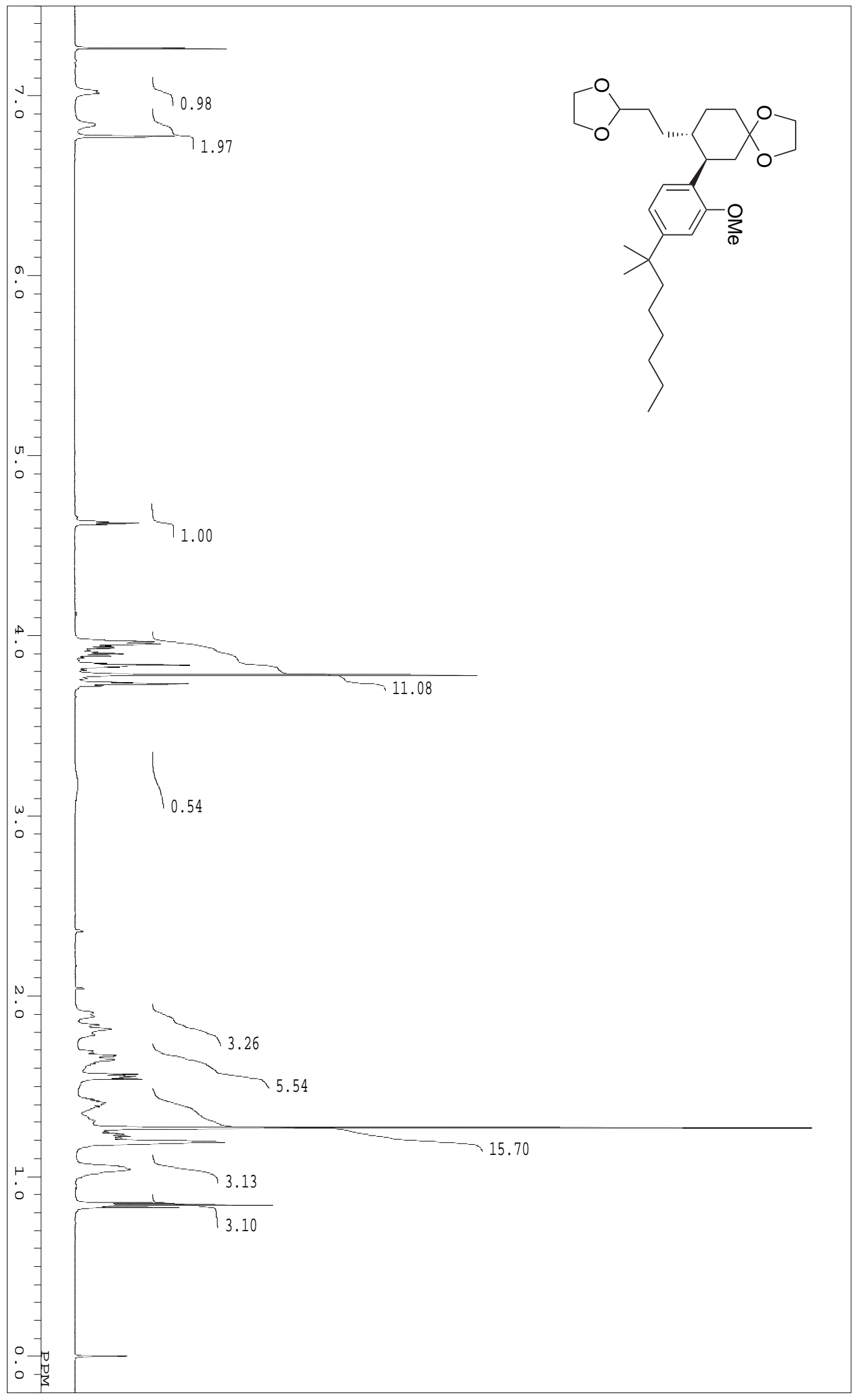




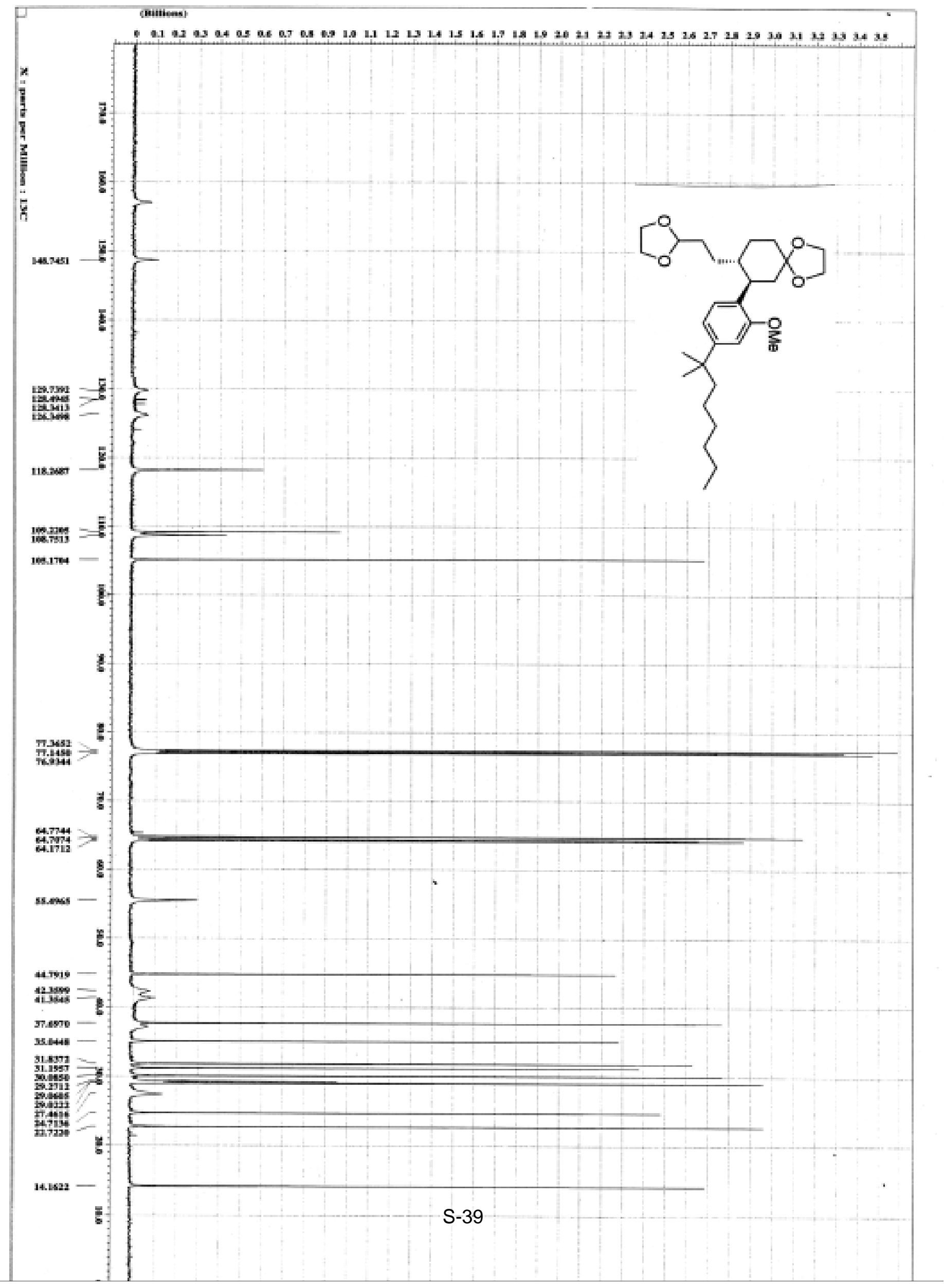




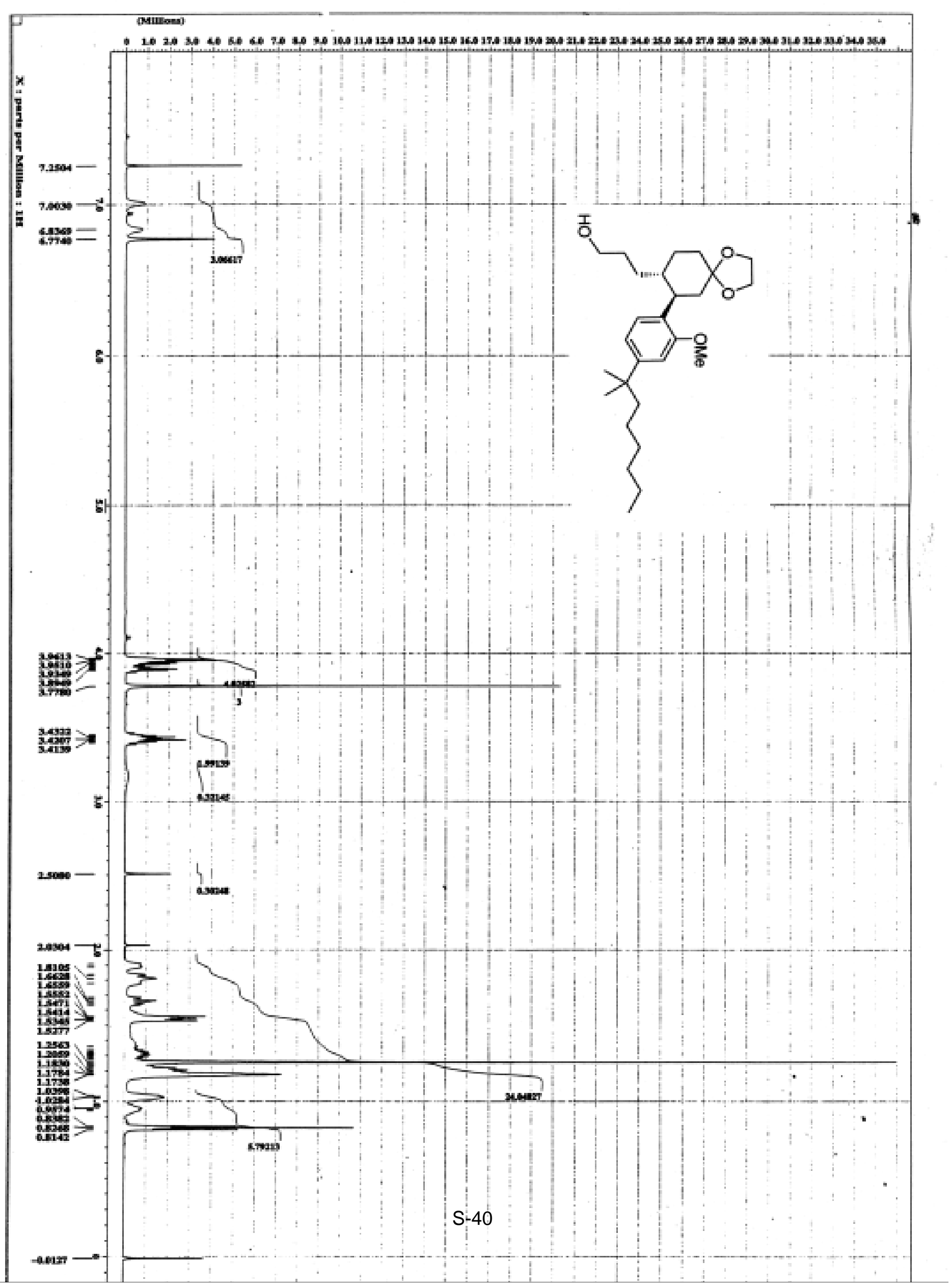




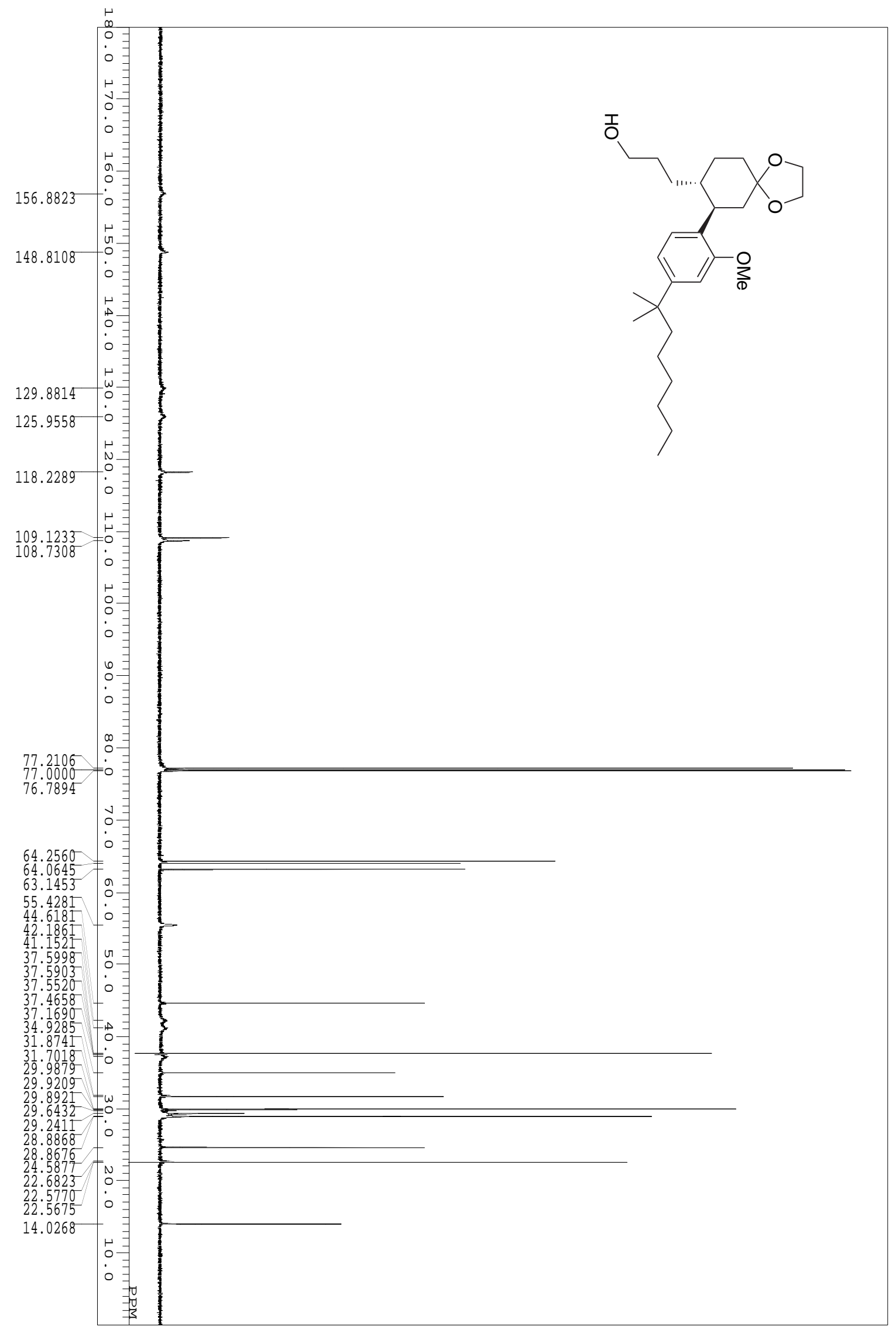




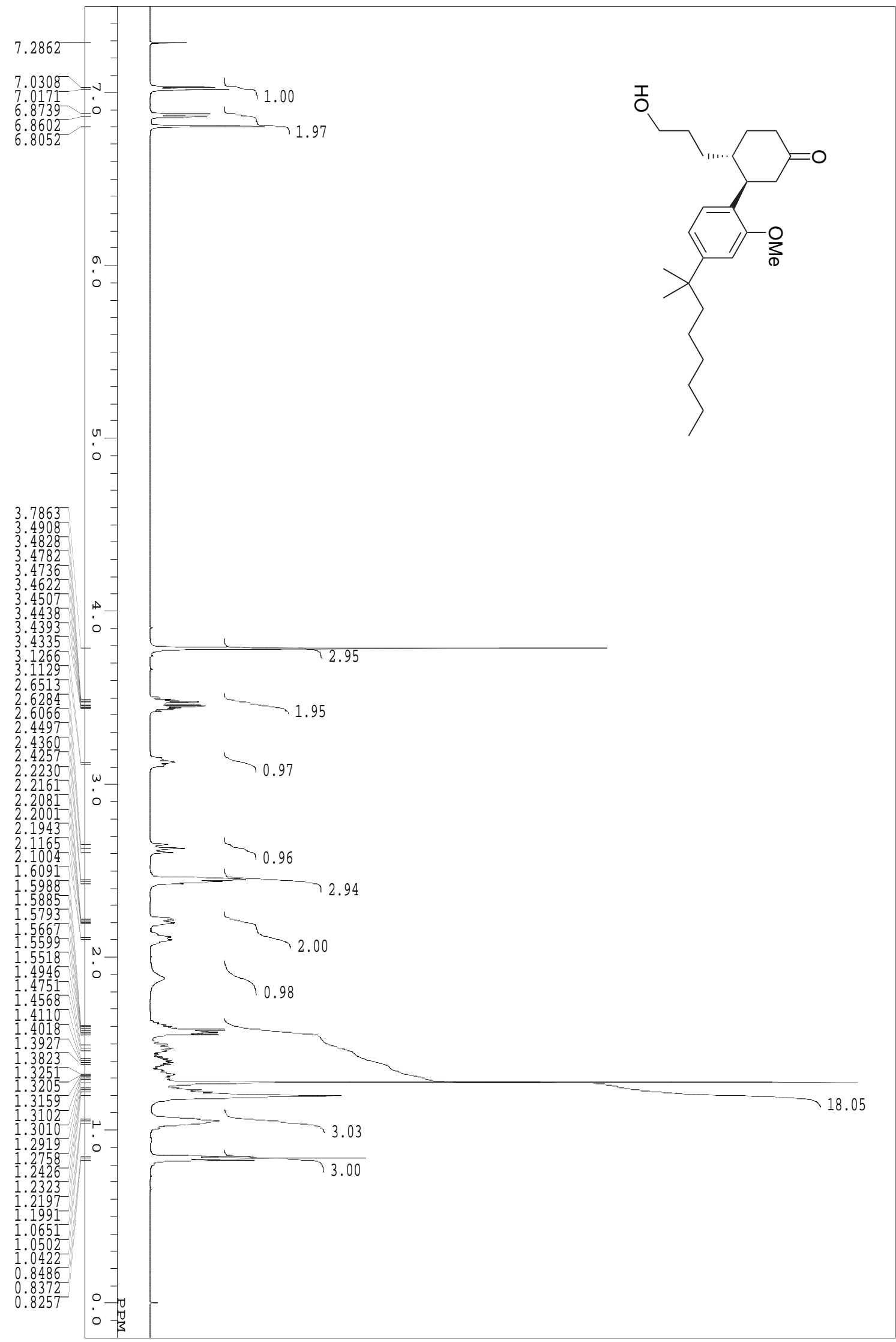




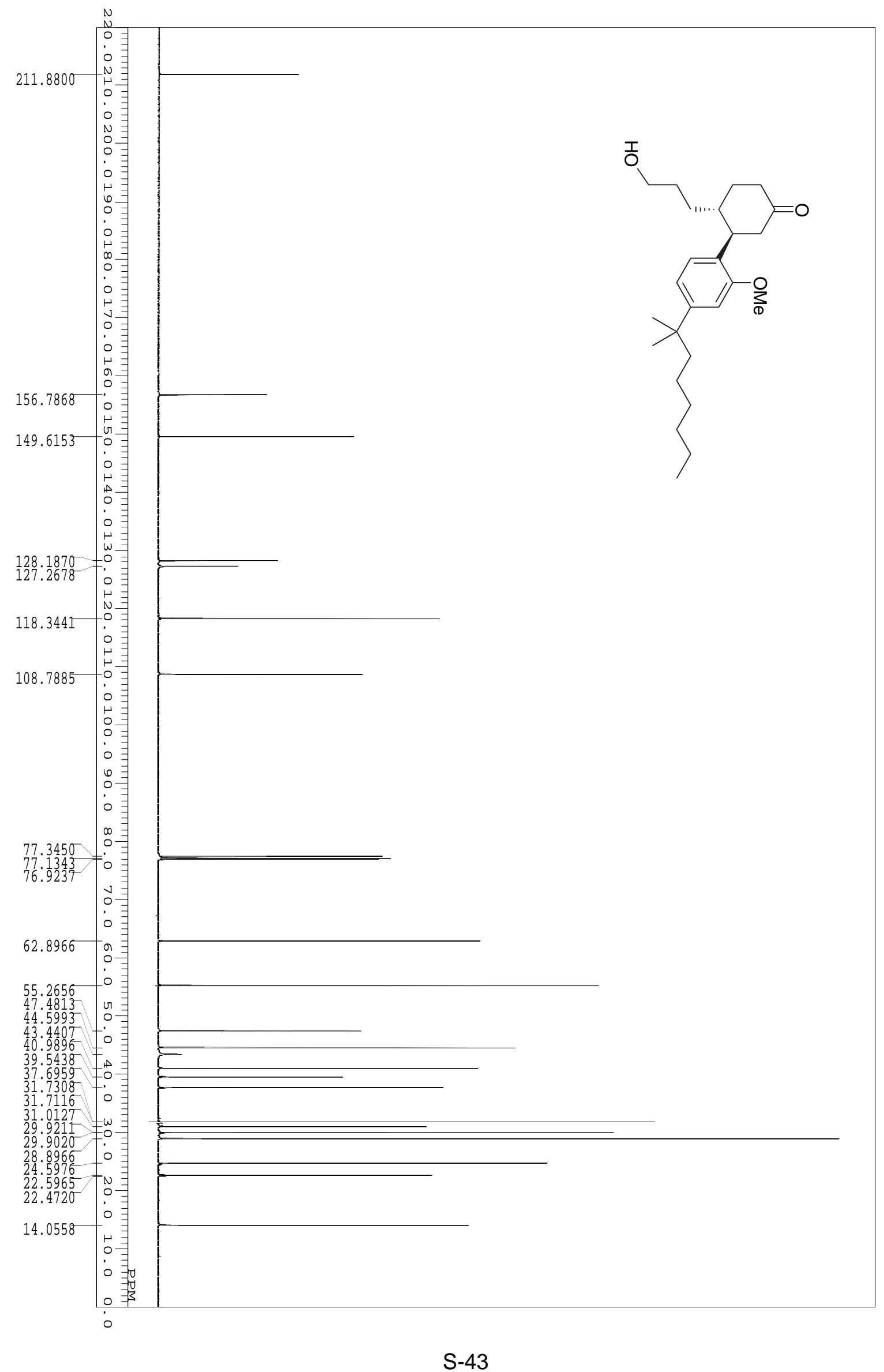




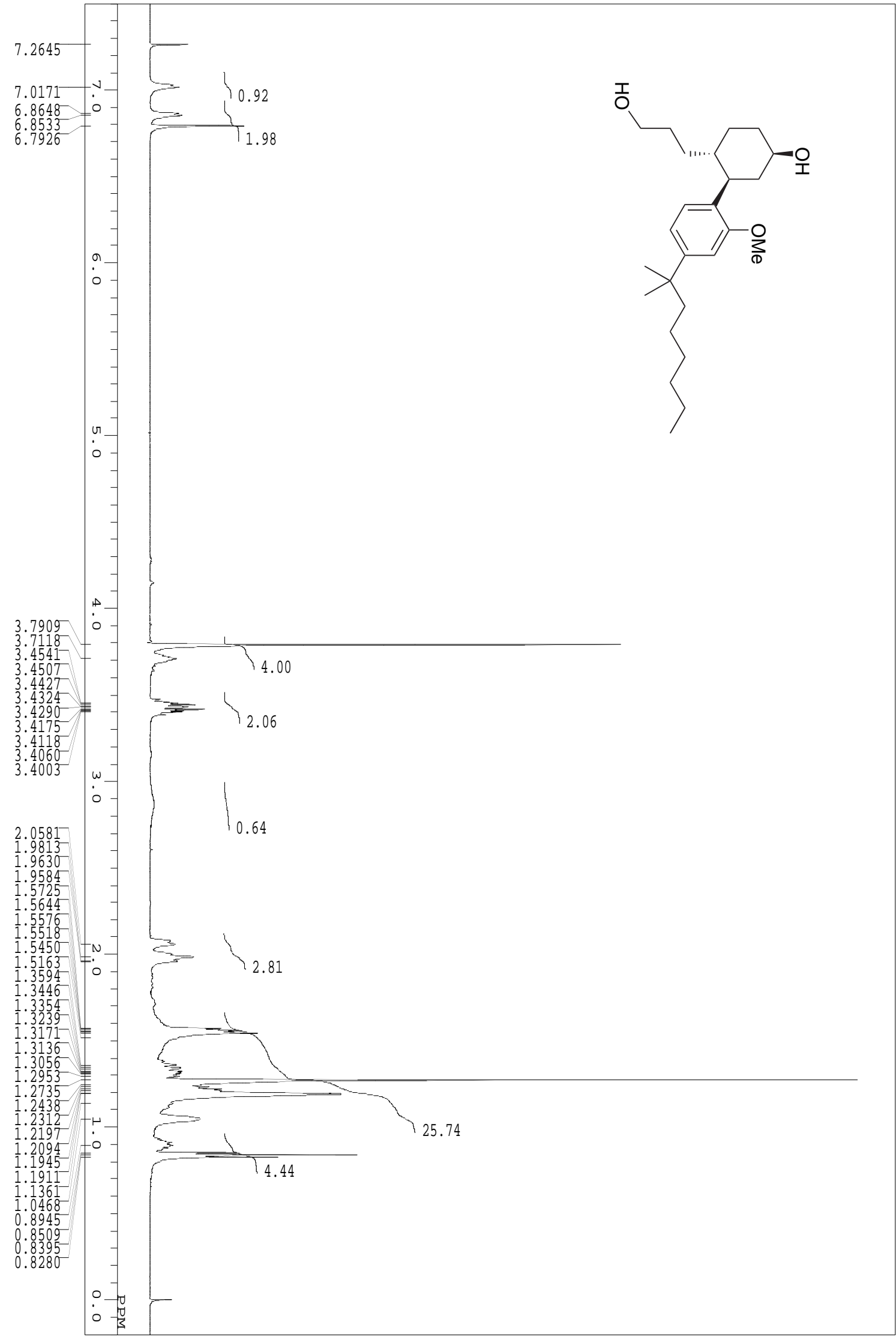




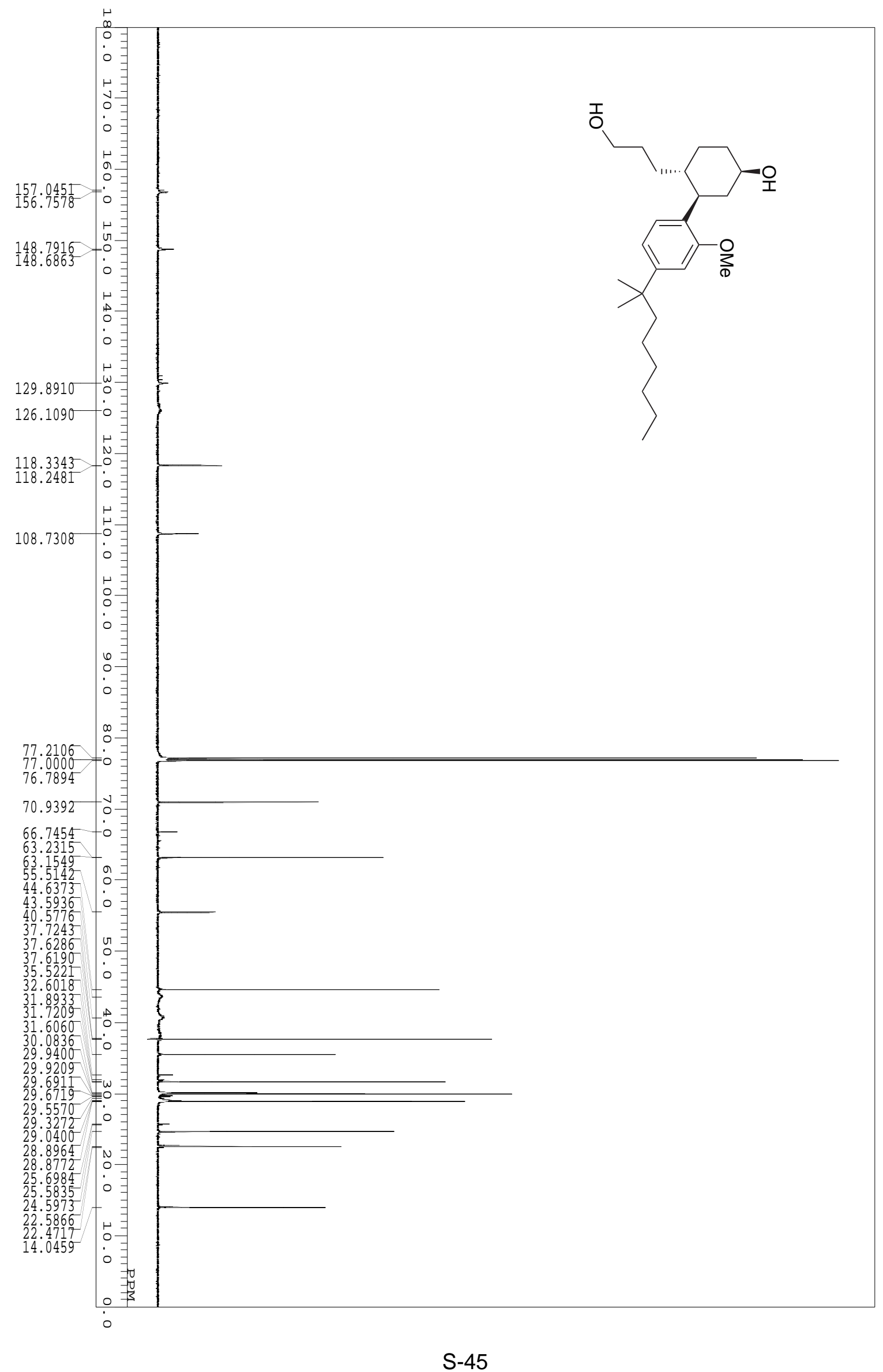




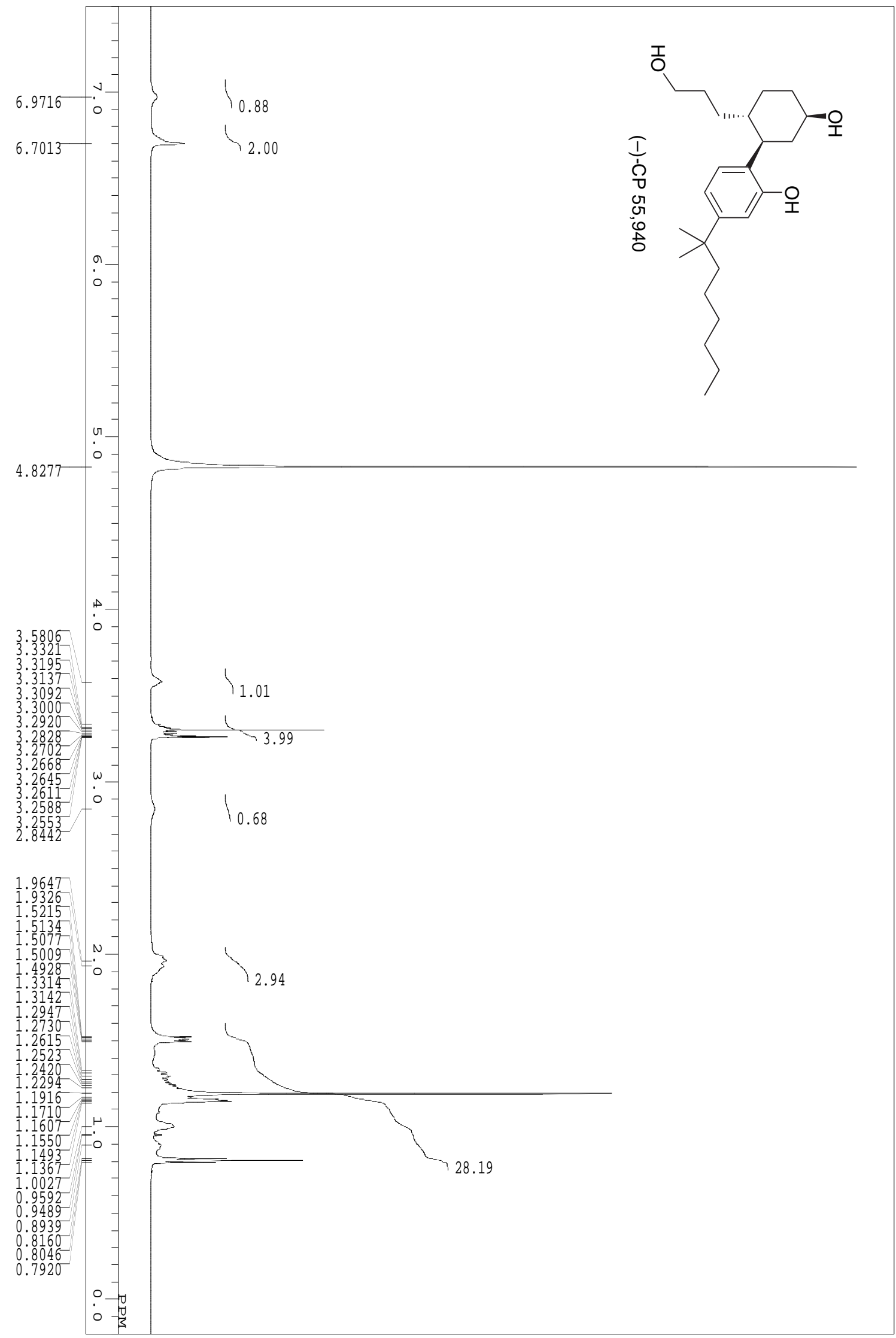




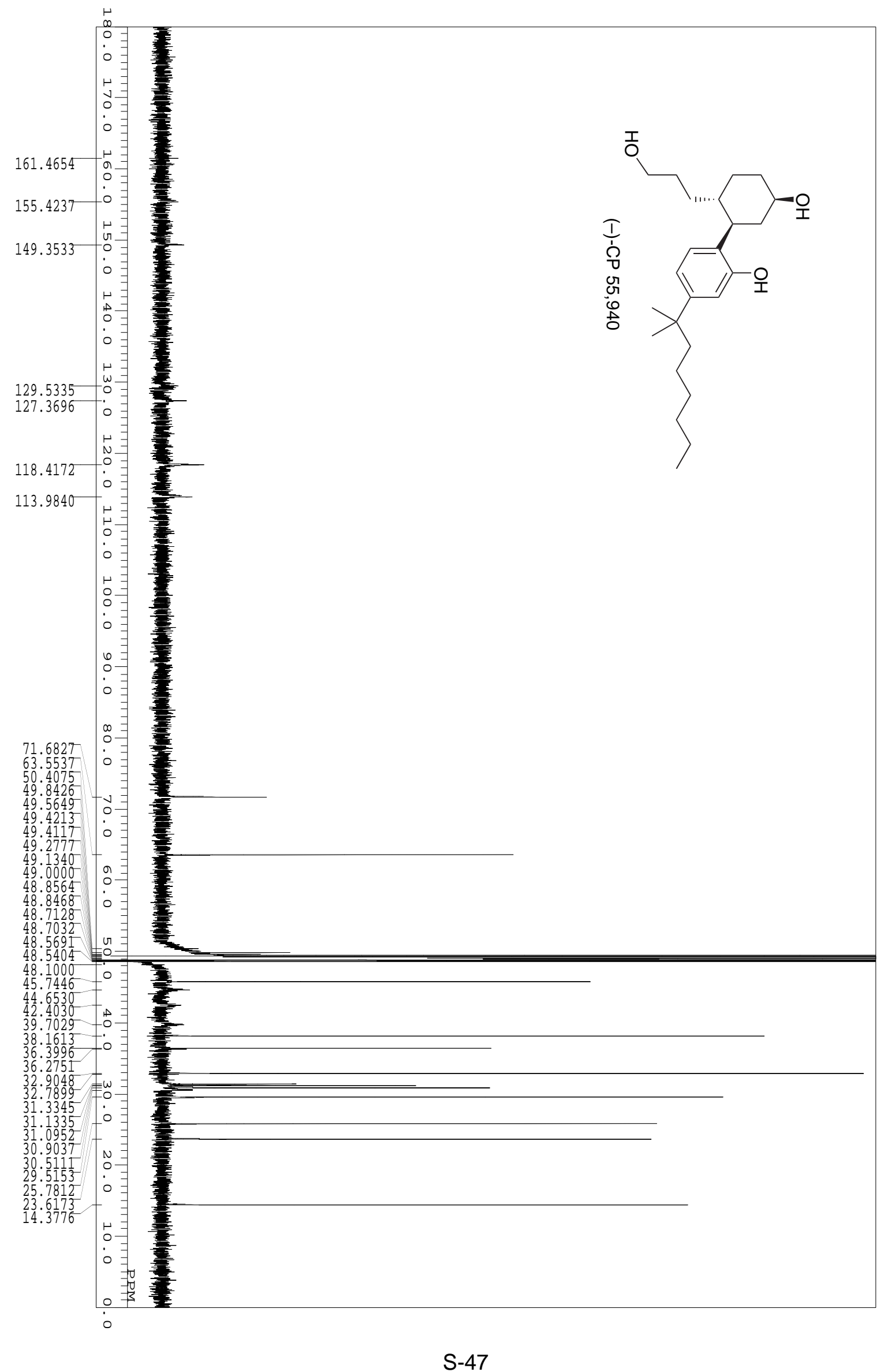

